\title{
An innovative immunotherapeutic strategy for ovarian cancer: CLEC10A and glycomimetic peptides
}

\author{
Laura L. Eggink', Katherine F. Roby ${ }^{2}$, Robert Cote ${ }^{1}$ and J. Kenneth Hoober ${ }^{1 *}(\mathbb{D}$
}

\begin{abstract}
Background: Receptors specific for the sugar N-acetylgalactosamine (GalNAc) include the human type II, C-type lectin receptor macrophage galactose-type lectin/C-type lectin receptor family member 10A (MGL/CLEC10A/CD301) that is expressed prominently by human peripheral immature dendritic cells, dendritic cells in the skin, alternatively-activated (M2a) macrophages, and to lesser extents by several other types of tissues. CLEC10A is an endocytic receptor on antigen-presenting cells and has been proposed to play an important role in maturation of dendritic cells and initiation of an immune response. In this study, we asked whether a peptide that binds in the GalNAc-binding site of CLEC10A would serve as an effective tool to activate an immune response against ovarian cancer.
\end{abstract}

Methods: A 12-mer sequence emerged from a screen of a phage display library with a GalNAc-specific lectin. The peptide, designated SVL4, and a shorter peptide consisting of the C-terminal 6 amino acids, designated sv6D, were synthesized as tetravalent structures based on a tri-lysine core. In silico and in vitro binding assays were developed to evaluate binding of the peptides to GalNAc-specific receptors. Endotoxin-negative peptide solutions were administered by subcutaneous injection and biological activity of the peptides was determined by secretion of cytokines and the response of peritoneal immune cells in mice. Anti-cancer activity was studied in a murine model of ovarian cancer.

Results: The peptides bound to recombinant human CLEC10A with high avidity, with half-maximal binding in the low nanomolar range. Binding to the receptor was $\mathrm{Ca}^{2+}$-dependent. Subcutaneous injection of low doses of peptides into mice on alternate days resulted in several-fold expansion of populations of mature immune cells within the peritoneal cavity. Peptide sv6D effectively suppressed development of ascites in a murine ovarian cancer model as a monotherapy and in combination with the chemotherapeutic drug paclitaxel or the immunotherapeutic antibody against the receptor PD-1. Toxicity, including antigenicity and release of cytotoxic levels of cytokines, was not observed.

Conclusion: SV6D is a functional ligand for CLEC10A and induces maturation of immune cells in the peritoneal cavity. The peptide caused a highly significant extension of survival of mice with implanted ovarian cancer cells with a favorable toxicity and non-antigenic profile.

Keywords: Glycomimetic peptides, Dendritic cells, CLEC10A, ASGPR-1, N-Acetylgalactosamine, Peritoneal cells, Ovarian cancer

\footnotetext{
* Correspondence: jkhoober@susavion.com

'Susavion Biosciences, Inc., 1615 W. University Drive, Suite 132, Tempe, AZ

85281, USA

Full list of author information is available at the end of the article
}

(C) The Author(s). 2018 Open Access This article is distributed under the terms of the Creative Commons Attribution 4.0 International License (http://creativecommons.org/licenses/by/4.0/), which permits unrestricted use, distribution, and reproduction in any medium, provided you give appropriate credit to the original author(s) and the source, provide a link to the Creative Commons license, and indicate if changes were made. The Creative Commons Public Domain Dedication waiver (http://creativecommons.org/publicdomain/zero/1.0/) applies to the data made available in this article, unless otherwise stated. 


\section{Background}

CLEC10A $\left(\mathrm{Ca}^{2+}\right.$-dependent lectin-type receptor family member 10A, CD301) is an endocytic receptor that has been proposed as a target for immunotherapy of cancer [1-3]. CType lectin receptors require $\mathrm{Ca}^{2+}$ for binding the sugar ligand, both to achieve correct structure of the binding site and coordination with sugar hydroxyl groups [4-7]. CLEC10A (also designated the macrophage galactose-type lectin, MGL) is expressed on dermal dendritic cells, immature peripheral dendritic cells, alternatively-activated M2a macrophages, and other tissues [1, 2, 8-11]. The receptor constitutively initiates a $\mathrm{Ca}^{2+}$ signal upon ligand-induced endocytosis [12]. $\mathrm{Ca}^{2+}$ and the ligand dissociate from the receptor in early endosomes; the ligand is processed through the MHC class I and II pathways for presentation to T cells while $\mathrm{Ca}^{2+}$ is transferred to the cytosol and the receptor is recycled [12, 13]. An elevation of cytosolic $\mathrm{Ca}^{2+}$ is the ubiquitous second messenger $[14,15]$ involved in stimulation of maturation and subsequent functions of dendritic cells (DCs) [16, 17].

CLEC10A is a pathogen-recognition receptor that is highly specific for structures that contain terminal $N$ acetylgalactosamine (GalNAc). Endogenous examples of these structures include the blood group A substance (GalNAc $\alpha 1,3[$ Fuc $\alpha 1,2]$ Gal-), in which GalNAc and fucose are linked to the penultimate residue, galactose (Gal) [18]. These structures tend to have low affinity for the receptor. Nevertheless, terminal glycans are often antigenic, and individuals with each blood type express antibodies against the other. The first step in O-glycosylation of cell membrane-bound and secreted glycoproteins occurs in the Golgi by a family of up to twenty distinct UDP- $N$-acetyl- $\alpha$-D-galactosamine:polypeptide $N$-acetylgalactosaminyltransferases (GALNTs), which attach GalNAc to the hydroxyl group of serine (Ser) or threonine (Thr) [19]. This reaction is essential for the synthesis of larger $\mathrm{O}$-glycans and the production of mucins, which are major glycoproteins engaged in maintenance of epithelial tissues [20]. An almost universal feature of cancer cells is the expression of an aborted $O$ glycan, in which only GalNAc is attached to Ser/Thr, a structure known as the Tn antigen [21]. A total of 96 glycoproteins bearing one or more Tn antigens was identified on human $\mathrm{T}$ lymphoblastoid cells (Jurkat cell line) and 33 glycoproteins were identified on human breast adenocarcinoma cells (MCF7 cell line) [22]. Antigenicity of the Tn structure was demonstrated in the mouse, and the induced antibodies provided protection against an implanted tumor cell line [23, 24]. Addition of multiple Tn antigens to mucin-derived peptides enhanced immunogenicity and promoted the use of these glycopeptides as vaccines [24-28]. Tumor cells also express the TF antigen (Galß1-3GalNAc $\alpha 1-O-S e r / T h r)$ [21, 29]. Whereas the appearance of $\mathrm{Tn}$ and TF antigens have been considered the result of incomplete assembly of the typical tri- or tetra-saccharide $O$-linked glycans, recent evidence suggests that a shift in regulatory pathways driven by membrane trafficking events leads to the shorter glycans on cancer cells [30].

Efficient engagement of CLEC10A requires multivalent ligands such as a fragment of the MUC1 protein bearing 9 Tn moieties $[2,28,31]$ or multimeric Tn-peptide structures $[24,32]$ that provide orders of magnitude greater avidity to the receptor than a single GalNAc residue. An immune response is initiated by internalization of the ligand by trimers of CLEC10A on DCs [33], antigen processing, migration over several days to draining lymph nodes, and subsequent presentation of the antigen to naïve, antigen-specific T cells [34-36]. The structure of the ligand influences the cellular response, with large Tn-bearing glycoproteins trapped in an endolysosomal compartment [28] whereas smaller glycopeptides are further processed in HLAI/HLAII compartments [2, 28].

The type II C-type lectin asialoglycoprotein receptor-1 (ASGPR-1, Ashwell-Morell receptor, CLEC4H1) on hepatic cells also binds GalNAc-containing structures [37, 38]. ASGPR-1 has a 60-fold greater preference for GalNAc over Gal [39]. Each healthy rat hepatocyte expresses 4 to $5 \times 10^{5}$ molecules of ASGPR-1 as binding sites for asialoorosomucoid [40] or $1.8 \times 10^{6}$ molecules as determined by an ASGPR-1-targeted antibody [41], which provides a surface concentration for the receptor of 0.8 to $1 \mu \mathrm{M}$. Although Gal is the terminal sugar on the multivalent glycans of asialo-orosomucoid [42], the protein binds ASGPR-1 with a $K_{D}$ of 2 to $7 \times 10^{-9} \mathrm{M}[40,43]$. Blood proteins and cells whose bound glycans have lost terminal sialic acid bind ASGPR-1, which internalizes the ligand for degradation [38]. Other major GalNAc/Gal-specific receptors include the type II C-type lectin CLEC4F, which is expressed by Kupffer cells in liver [44]; and the scavenger C-type lectin receptor, with a preference for $\mathrm{Gal}$ [45]. The mouse expresses two forms of MGL, MGL1 specific for Gal and MGL2 specific for GalNAc [8]. Human CLEC10A is similar to mouse MGL2, preferentially binds GalNAc, and recognizes terminal GalNAc-containing residues such as the Tn antigen [9].

We asked whether the collective evidence of the role of ligands of CLEC10A, such as promoting DC maturation, $\mathrm{T}$ cell activation, and initiation of an immune response would coalesce into an effective anti-cancer therapy. To achieve this goal, the ligand should serve as a 'trigger' to initiate a cascade of events that will lead to activation of the immune system $[1,2,31,46]$. Given that natural ligands of CLEC10A that contain GalNAc bind with low affinity and are antigenic, we considered whether a multivalent peptide mimetic of GalNAc would serve this purpose. We previously described efficacy of a tetravalent, 12-amino acid peptide sequence, svL4, which 
emerged from a screen of a phage display library [47], in a murine model of a brain glioma in combination with brief radiation [48]. Here we report that a tetravalent structure with the C-terminal 6-mer sequence, sv6D, retains the binding activity of svL4 and is a more potent stimulator of immune cells. The peptides bind with high avidity to lectins specific for GalNAc. Analysis of the sequences of the peptides with MHC binding databases $[49,50]$ predicted that they would not likely be presented by MHC class I or MHC class II molecules in humans or induce production of antibodies. Indeed, no antibodies were detected in mouse sera after alternateday subcutaneous injections over 3 months. Subcutaneous injection of the peptides stimulated proliferation and maturation of immune cells in the peritoneal cavity. Effectiveness as an anti-cancer approach is demonstrated by the inhibition of accumulation of ascites in a murine model of ovarian cancer.

\section{Methods \\ Animals}

C57BL/6 and Balb/c mice were obtained from Charles River Laboratories (Wilmington, MA). Studies of the effects of subcutaneous injection of peptides on populations of peritoneal cells were performed in AAALAC-accredited facilities at Biomodels LLC, Watertown, MA (IACUC approval number 13-0611-01). Studies with the murine model of ovarian cancer were conducted at the University of Kansas Medical Center, Kansas City, KS (IACUC approval number 2015-2288). Cells of an ovarian epithelial cancer line, ID8 [51], were implanted into the peritoneal cavity of female C57BL/ 6 mice at a dose of $6 \times 10^{6}$ cells. All animals were weighed at least weekly throughout these studies. Accumulation of ascites was monitored by increase in body weight, and animals were euthanized when end-stage behavior was expressed. No animals were euthanized for any reason unrelated to the cancer prior to termination of the experiment. Kaplan-Meier survival curves were analyzed by the Mantel-Cox log-rank test.

\section{Synthesis of peptides}

The sequence of svL4 was identified by screening a 12mer phage display library (New England BioLabs, Ipswich, MA) with the lectin from Helix pomatia, which is specific for GalNAc $[47,52]$. The consensus sequence was incorporated into a tetravalent structure based on the concept of avidity of binding to receptors as a function of ligand density and entropic factors [38, 43, 5355]. Multivalent peptides were synthesized by standard solid-phase chemistry utilizing Fmoc (9-fluorenylmethoxycarbonyl)-protected amino acids by CBL Biopharma LLC (Patras, Greece). The tri-lysine 'core' was synthesized on the solid-phase resin and extended with the sequence GGS. The 'arms' with C-terminal G were synthesized separately by standard chemistry and condensed in solution with the core [56]. Modifications at the C-terminus consisted of an amide group (no tag) or extensions with $\varepsilon$-biotinyl-lysinyl-amide. The sequence GGGS was included in the structure as a linker between the mimetic sequence and the tri-lysine core. Derivatives of svL4 were also synthesized to determine whether subsets of the sequence have differing activities. Structures, designations and molecular weights of svL4 and derivatives are shown in Table 1.

\section{Preparation of endotoxin-negative peptide solutions}

The peptides were purified to greater than $95 \%$ by HPLC on a XDB-C8 column using a gradient of $5 \%$ to $25 \%$ acetonitrile in $0.1 \%$ trifluoroacetic acid in water at a column temperature of $60{ }^{\circ} \mathrm{C}$. Quality of the synthetic product, including correct synthesis and purity, was assessed by MALDI and ESI mass spectroscopy. Lyophilized peptides were dissolved in $100 \mathrm{mM} \mathrm{NaCl}$, neutralized to $\mathrm{pH} 5$, and adsorbed onto a CM-Sephadex C-25 column $(2.5 \times 10 \mathrm{~cm})$. The column was washed with $200 \mathrm{mM}$ $\mathrm{NaCl}$ to ensure removal of lipopolysaccharide (LPS) prior to elution of svL4 with $500 \mathrm{mM} \mathrm{NaCl}$. LPS was not detected in the peptide solution eluted from the CMSephadex column $(<0.01 \mathrm{EU} / 10 \mathrm{mg}$ peptide). Although sv6D and svL4 have the same molecular charge $(+8.4$ at $\mathrm{pH}$ 7.0), elution of sv6D from the CM-Sephadex column required $1 \mathrm{M} \mathrm{NaCl}$. Peak fractions were combined and diluted with endotoxin-negative water (HyClone Laboratories, Inc., Logan UT) to achieve a $\mathrm{NaCl}$ concentration of $150 \mathrm{mM}$. The sample was further diluted to the desired concentration with endotoxin-negative phosphatebuffered saline, pH 7.4 (PBS) (Sigma-Aldrich, St. Louis, $\mathrm{MO}$ ), and filter-sterilized. The presence of LPS was assayed by a quantitative colorimetric assay with the Limulus amebocyte lysate (LAL, Lonza, Walkersville, MD). Concentration of svL4 was determined with the bichinichonic (BCA) assay (Pierce Biotechnology, Inc., Rockland, IL) with the dansylated peptide [47] or bovine serum albumin as standards. Absorbance of analyzed solutions provided an extinction coefficient for svL4 of 22 OD units/ $\mathrm{mg} / \mathrm{mL}$ at $210 \mathrm{~nm}$, which was also used for determination of concentration of sv6D. This value was supported by calculations from absorbance coefficients of peptide bonds in small proteins [57] and was used as a convenient measure of concentration.

Table 1 Peptides synthesized as subsets of svL4

\begin{tabular}{lll}
\hline Sequence & Code & MW \\
\hline$\left[(\text { VQATQSNQHTPR-GGGS })_{2} \mathrm{~K}_{2} \mathrm{~K}-\mathrm{NH}_{2}\right.$ & $\mathrm{sVL} 4$ & 6826 \\
{$\left[(\mathrm{VQATQS}-\mathrm{GGGS})_{2} \mathrm{~K}_{2} \mathrm{~K}-\mathrm{NH}_{2}\right.$} & $\mathrm{svC1}$ & 3893 \\
{$\left[(\mathrm{VSNQH}-\mathrm{GGGS})_{2} \mathrm{~K}_{2} \mathrm{~K}-\mathrm{NH}_{2}\right.$} & $\mathrm{svD2}$ & 3697 \\
{$\left[(\mathrm{NQHTPR}-\mathrm{GGGS})_{2} \mathrm{~K}_{2} \mathrm{~K}-\mathrm{NH}_{2}\right.$} & $\mathrm{sv6D}$ & 4369 \\
\hline
\end{tabular}




\section{Binding assays}

Solid-phase binding assays were performed with streptavidin-, protein A/G-, or Nickel-coated microtiter plates (Pierce). His-tagged or Fc-fusion recombinant receptors (R\&D Systems, Minneapolis, MN) were reconstituted in PBS. Sufficient receptors were added to wells to saturate the coating. His-tagged receptors were added to each well at a 5 -fold excess over the stated capacity of the $\mathrm{Ni}$ coating to minimize non-specific binding of the peptide. Wells were washed three times with binding buffer $(25 \mathrm{mM}$ Tris $\mathrm{HCl}, \mathrm{pH} 7.4,150 \mathrm{mM} \mathrm{NaCl}, 0.05 \%$ Tween-20) to remove unbound receptor and $50 \mu \mathrm{L}$ of $2 \mu \mathrm{M}$ biotinylated peptide in binding buffer were added and allowed to incubate for $1 \mathrm{~h}$. The wells were washed four times with binding buffer and then incubated with $50 \mu \mathrm{L}$ of $1 \mu \mathrm{g} / \mathrm{mL}$ streptavidin conjugated with peroxidase (Sigma-Aldrich) for $1 \mathrm{~h}$. The wells were washed five times with binding buffer and $50 \mu \mathrm{L}$ of peroxidase substrate (1-Step ${ }^{\mathrm{Tm}}$ Ultra TMB, Pierce) were added. After several minutes to allow color development, the reaction was stopped with $50 \mu \mathrm{L} 1 \mathrm{M} \mathrm{H}_{3} \mathrm{PO}_{4}$ and absorbance was measured at $450 \mathrm{~nm}$. Bound streptavidin was quantitated by the specific activity of peroxidase (absorbance/ng protein conjugate/min) under the conditions of the assay.

\section{Cytokine assays}

An allogenic mixed leukocyte reaction was performed with $5 \times 10^{3}$ human monocyte-derived DCs co-cultured with $1 \times 10^{5} \mathrm{CD}^{+} \mathrm{T}$ cells in X-VIVO 20 medium (Lonza) by Astarte Biologics, Inc. (Bothell, WA). IFN- $\gamma$ in the medium was assayed over a period of 5 days with a Meso Scale Discovery assay kit (Meso Scale Discovery, Rockville, $\mathrm{MD})$. For analysis of a cytokine response in vivo to subcutaneous injection of peptide, 6 to 8 week-old female $\mathrm{Balb} / \mathrm{c}$ mice were anesthetized with isoflurane and inoculated with $5 \times 10^{5} 4 \mathrm{~T} 1$ breast cancer cells in the 4th mammary fat pad. When tumors reached a volume of at least $500 \mathrm{~mm}^{3}$, animals were randomized into groups of 3 and dosed with either 0.1 or $1.0 \mathrm{nmole} / \mathrm{g}$ of svL4. At $4 \mathrm{~h}$ post dose, terminal blood was collected from 3 animals per group and prepared for serum. Sera were also collected from healthy Balb/c mice by the same procedure. Changes in the levels of cytokines/chemokines in sera from breast cancer-bearing and healthy mice were analyzed with the mouse L-308 membrane array by RayBiotech, Inc. (Norcross, GA).

\section{Flow Cytometry}

Healthy C57BL/6 male mice, 10 weeks old, were injected subcutaneously with peptides on alternate days. Peritoneal cells were isolated from mice $24 \mathrm{~h}$ after dosing by injecting ice cold PBS (containing 3\% FBS) into the peritoneal cavity, gently massaging the abdomen, and then collecting the fluid, which was transferred into $\mathrm{K}_{2}$ EDTA-treated tubes for evaluation of specific biomarkers. Cells from three mice in each group were pooled, counted and divided among FACS tubes $\left(1 \times 10^{6}\right.$ cells per tube). Cells were washed once in PBS containing 3\% FBS, then stained with 0.25 to $1 \mu \mathrm{g}$ of fluorescently conjugated antibody per $10^{6}$ cells in $100 \mu \mathrm{L}$ of buffer as recommended by the manufacturer (Table 2).

Cells were incubated with the antibodies for $30 \mathrm{~min}$ at $4{ }^{\circ} \mathrm{C}$ in the dark. Following staining, the cells were washed two times with $\mathrm{PBS} / 3 \% \mathrm{FBS}$ and immediately analyzed with a MACSQuant flow cytometer (Miltenyi Biotech, Inc., San Diego, CA). Compensation was performed using single stain tubes for each color present in the analysis as well as an unstained control sample. Collection of flow cytometric data and analysis with Flowjo software, version 10.0.6 (FlowJo, LLC, Ashland, OR) were performed by Biomodels LLC (Watertown, MA).

\section{Antigenicity assay}

The sequence of one arm of svL4 or sv6D was conjugated to keyhole limpet hemocyanin (KLH) and injected into rabbits at two week intervals (total of 3 injections) (New England Peptide, Inc., Gardner, MA). Two weeks after the final injection, sera were prepared. Mice were injected with a peptide every other day over a period of 3 months (total $\sim 45$ injections), blood was then collected by cardiac puncture and sera were prepared. Rabbit serum was diluted 1: 10 , whereas mouse serum was diluted $1: 1$ or $1: 5$ with PBS containing $0.05 \%$ Tween-20 (PBST). Sera were incubated in microtiter wells coated with protein $\mathrm{A} / \mathrm{G}$ (Pierce) for $90 \mathrm{~min}$. The wells were washed three times with PBST, and then incubated with $50 \mu \mathrm{L}$ of $1 \mu \mathrm{M}$ biotinylated svL4 or sv6D for $1 \mathrm{~h}$. The wells were washed four times with PBST,

Table 2 List of cell surface markers used in this study

\begin{tabular}{llll}
\hline Antibody & Source & Catalog no. & Cell type marker \\
\hline CD11b-APC & BioLegend & 101,212 & Macrophage \\
CD11C-Pacific Blue & BioLegend & 117,322 & Myeloid Cell, DC \\
CD11C-VioBlue & Miltenyi & $130-102-797$ & Myeloid Cell, DC \\
CD3E-VioBlue & Miltenyi & $130-102-203$ & T Cell \\
CD4-APC & BioLegend & 100,412 & TH Cell \\
CD8a-PE & BioLegend & 100,708 & Cytotoxic T Cell \\
CD19-FITC & BioLegend & 115,506 & B Cell \\
CD69-FITC & BioLegend & 104,505 & Cell Activation \\
CD73-Brilliant Violet & BioLegend & 127,215 & B Memory Cell \\
CD80-APC & BioLegend & 104,713 & B Cell Activation \\
CD86-APC & BioLegend & 105,011 & Cell Activation \\
CD273-PE & BioLegend & 107,205 & B Memory Cell \\
F4/80-PE & BioLegend & 123,110 & Macrophage \\
Ly6C-FITC & Miltenyi & $130-093-134$ & Monocyte \\
NK1.1-APC & Miltenyi & $130-095-869$ & NK Cell \\
\hline
\end{tabular}


incubated $1 \mathrm{~h}$ with $1 \mu \mathrm{g} / \mathrm{mL}$ streptavidin-peroxidase conjugate, and washed four times with PBST. Peroxidase activity was assayed as above under Binding Assays.

\section{Results}

\section{Peptides as mimetics of GalNAc}

The functional sequence of svL4 was identified through a screen of a phage display library with the GalNAc-specific lectin from the snail Helix pomatia [47]. To investigate further its ability to bind to human GalNAc-specific lectins, in silico molecular modeling was performed. Whereas the crystal structure of CLEC10A has not been reported, that of ASGPR-1 (CLEC4H1) was determined [7]. The extensive homology between CLEC10A and ASGPR-1 allowed generation of a likely structure for CLEC10A with SWISSMODEL Deep View [58, 59]. The CABS-dock modeling program [60] was used to predict whether the peptide would bind to ASGPR-1 and CLEC10A. This method searches for a binding site on the protein without prior assignment and defines the most probable peptide conformation. The docking program accommodated svL4 in the carbohydrate-recognition domain (CRD) in a hair-pin conformation (RMSD $=0.868 \AA$ ) (not shown). As shown in Fig. 1a, the shorter sv6D, with a length dimension approximately two-times that of a sugar residue, was accommodated within the CRD of ASGPR-1. A portion of the linker was included in the peptide (i.e., NQHTPRGG) to indicate the orientation of the peptide and, by extension, the remainder of the tetravalent peptide. The GG sequence is more clearly seen after energy minimization in the model rendered by ArgusLab in Fig. 1b. Similar binding predictions were obtained with pepATTRACT [61] and
MDockPeP [62], which are blind docking programs that allow the fully flexible peptide to adapt to surface properties of the proteins $[63,64]$. ASGPR-1, and by homology CLEC10A, has an acidic GalNAc binding site, which may contribute through electrostatic interaction to binding avidity of the positively-charged peptide. The docking programs orient the peptide with the $\operatorname{Arg}(\mathrm{R})$ residue near the sequence Gln-Pro-Asp (QPD) that specifies binding of Ctype lectins to GalNAc residues (indicated in Fig. 1c) [65, 66]. In silico replacement of QPD with Glu-Pro-Asn (EPN), the sequence that has been described as a determinant for binding of mannose $[65,66]$, as occurs in the mannose receptor and DC-SIGN (dendritic cell-specific intercellular adhesion molecule (ICAM)-3 grabbing nonintegrin, CD209) [67], did not significantly alter the predicted binding of sv6D to CLEC10A. The flexibility of the peptide likely allows interaction of the Arg residue with negatively-charged Asp or the nearby Glu. As a further test, the CABS-dock program predicted much weaker binding of sv6D to DC-SIGN (RMSD $=4.477$ to $7.405 \AA$ compared with 0.7611 to $1.421 \AA$ for ASGPR-1 and CLEC10A) and with significantly lower predicted binding energy (not shown). The lack of binding to DC-SIGN, as described below, apparently results from the low homology of the amino acid sequences of the receptors within the CRD. These results suggest that specificity of peptide binding in the CRD is largely provided by the properties of the protein surface, as is typical for most peptideprotein interactions [63]. Although the conformation of the CRD of the GalNAc-specific lectin from Helix pomatia is similar to that of C-type lectins [52], the snail lectin lacks a QPD sequence or significant homology to
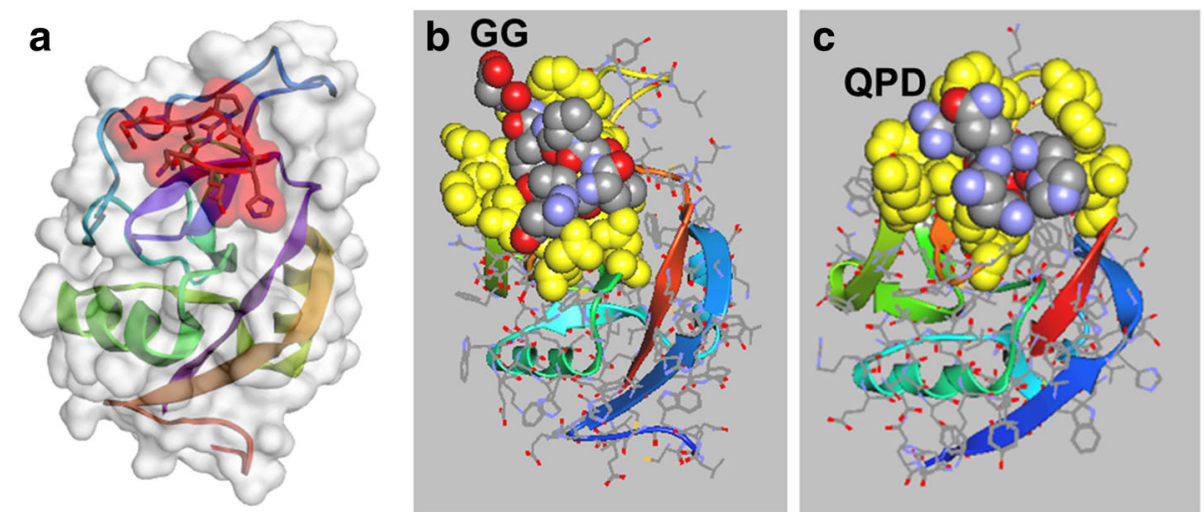

Fig. 1 Docking of sv6D to receptors. a In silico docking of an arm of SV6D (NQHTPRGG) to the carbohydrate-recognition domain of ASGPR-1 (accession number 1DV8) with CABS-dock (RMSD $=0.7611 \AA$ ) [60]. The peptide is enclosed in red shading that delineates the space-filling molecular structure. $\mathbf{b}$ The structure in (a) as rendered in ArgusLab 4.0 .1 (predicted binding energy, $\Delta \mathrm{G}^{\prime}=-40 \mathrm{~kJ} / \mathrm{mol}$ ). Amino acids in the binding site that interact with the peptide are colored in yellow as space-filling structures. sv6D is colored as carbon, grey; nitrogen, blue; and oxygen, red. A portion of the linker to the remainder of the tetravalent structure is indicated as GG. c The structure of CLEC10A was generated with SWISS-MODEL Deep View [58, 59] from the structure of ASPGR-1. Docking was modeled with CABS-dock (RMSD = 1.421 Å) and downloaded into ArgusLab 4.0.1 (predicted binding energy, $\Delta \mathrm{G}^{\prime}=-38 \mathrm{~kJ} / \mathrm{mol}$ ). The binding site and peptide are colored as in (b). The location of the QPD sequence is indicated. Helical and beta-strand secondary structures of the protein are shown as colored ribbons 
CLEC10A. However, the CABS-dock program indicated an $\mathrm{RMSD}=1.604 \AA$ for binding of sv6D, with predicted binding energy of $\Delta G^{\prime}=-38 \mathrm{~kJ} / \mathrm{mol}$ (not shown).

\section{Binding to recombinant receptors}

Solid-phase binding assays were performed with recombinant human receptors. Three variations of the binding assay were used in this study, all of which allowed the arms of the tetravalent peptide to have full flexibility. (i) Biotinylated peptide was bound in microtiter wells coated with streptavidin and incubated with recombinant human receptors. After extensive washing, the bound receptor was measured by peroxidase conjugated to a receptor-specific antibody. (ii) The extracellular domains of receptors, which were fused with the Fc domain of immunoglobulin IgG, were bound in wells coated with protein A/G. Biotinylated peptide was incubated with the receptors and, after extensive washing, bound peptide was measured with streptavidin conjugated with peroxidase. Or (iii), recombinant receptors with a poly-His tag were bound to Nickel-coated wells and incubated with biotinylated peptide. svL4 and sv6D contain His residues (see Table 1) and can bind to the Ni coating, which was minimized by adding sufficient poly-His-tagged receptor to saturate the Ni coating.

In these assays, svL4 bound to CLEC10A and, as confirmation of GalNAc mimicry, also to ASGPR-1 (Fig. 2). Although a significant consensus was found for the 12mer sequence of svL4 in the screen of a phage display library with the GalNAc-specific lectin [47], subsets of the sequence were synthesized as shown in Table 1 to test the activity of the $\mathrm{N}$-terminal and $\mathrm{C}$-terminal halves in comparison with the full-length svL4. As shown in Fig. 2a, the C-terminal half (sv6D) bound as strongly as the full-length sequence to CLEC10A and to ASGPR-1. Retention of the N-terminal half ( $\mathrm{svC1}$ ) was near the level of blank wells. The mid-section of the svL4 sequence (svD2) bound weakly to these receptors.

A survey of other receptors showed that svL4 or sv6D did not bind significantly to CLEC9A, a C-type lectin receptor expressed on monocytes and DCs [68]; DC-SIGN, a mannose-specific lectin-type receptor $[67,69,70]$; or Siglec-1, which is specific for terminal Neu5Ac-Gal/GalNAc-sequences on complex glycans [71, 72]. Binding was not detected with CD44, a receptor for hyaluronic acid [73], or IL-4R, a receptor for IL-4 (Fig. 2b). Of the receptors we have assayed thus far, the peptides bound to those specific for GalNAc, which included CLEC4F, a GalNAcbinding receptor expressed by Kupffer cells that is also homologous to ASGPR-1 [44].

To further determine whether sv6D interacts with the actual sugar binding site, the ability of sv6D to compete with GalNAc-PAA for binding was assayed. As shown in Fig. 3a, sv6D inhibited binding of GalNAc-PAA to CLEC10A from rat as well as human ASGPR-1. This experiment suggests that the peptide has an avidity over an order of magnitude greater than that of the multivalent GalNAc-PAA. Further support for the mimicry of sv6D was the finding that an antiserum that was raised in rabbits against the sv6D sequence (NQHTPR) conjugated to KLH also bound GalNAc-PAA (Fig. 3b).

Binding of sugar ligands to $\mathrm{C}$-type lectins requires $\mathrm{Ca}^{2+}$ bound at three or four sites in the protein $[5-7,67]$.
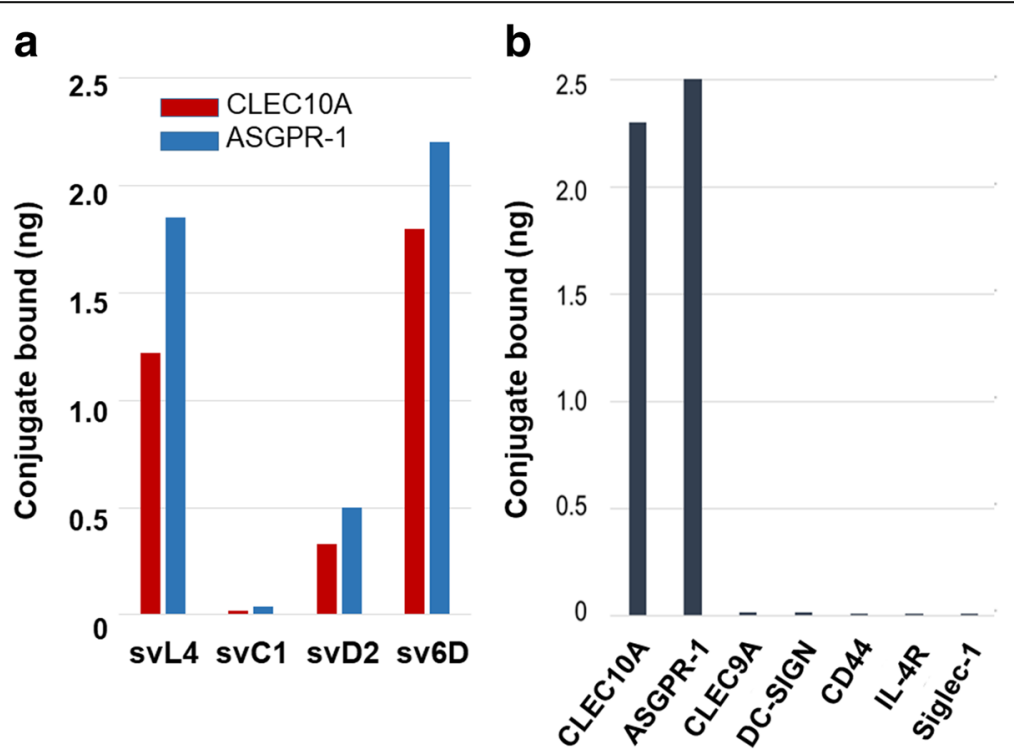

Fig. 2 Binding activity of SVL4 and sV6D to CLEC10A and ASGPR1. a Solid-phase binding assays of subsets of svL4 were performed with recombinant human CLEC10A (red) or ASGPR-1 (blue) as described in Materials and Methods. The peptide structures are shown in Table 1. The figure shows representative data from 3 independent experiments. $\mathbf{b}$ Binding of sV6D to recombinant human receptors. Extent of binding was corrected for the masses of the recombinant proteins, assuming a single binding site per subunit. The data shown are representative of the results of 4 independent assays 

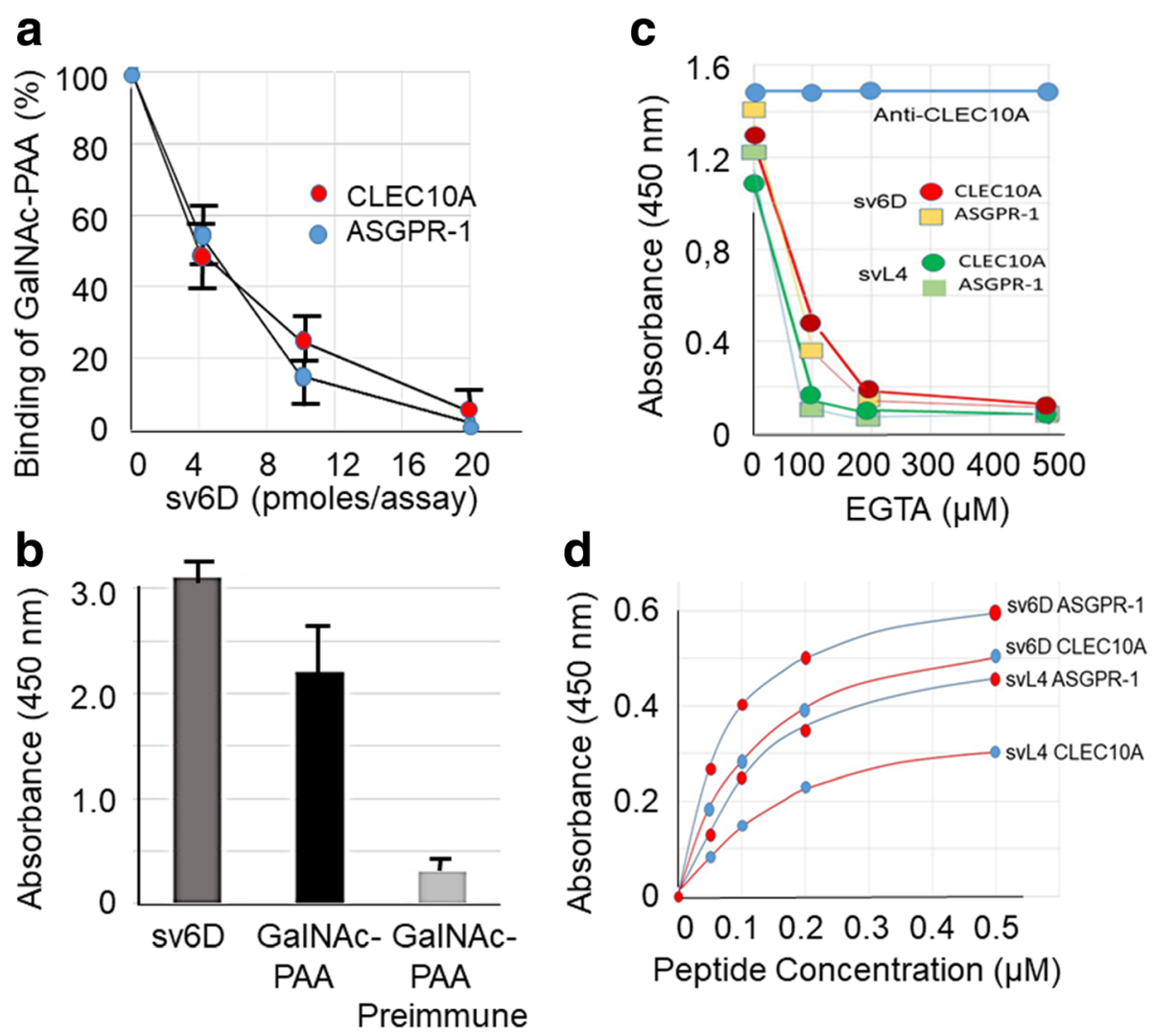

Fig. 3 sv6D as a mimetic of GalNAc. a Inhibition by sv6D of binding of multivalent GalNAc-PAA (GlycoTech Corp., Frederick, MD) to recombinant rat CLEC10A and human ASGPR-1. The reaction mixture included approximately 200 pmoles of biotinylated GalNc-PAA and increasing concentrations of peptide. The figure includes values \pm S.D. from 3 independent experiments. b Biotinylated sv6D or GalNAc-PAA were incubated with rabbit antiserum raised against the 6D sequence (NQHTPR) conjugated to KLH. Binding was detected with streptavidin-peroxidase conjugate. Similar data were obtained in 2 experiments. $\mathbf{c}$ Inhibition by EGTA of binding of sv6D (red, yellow) or svL4 (dark green, light green) to CLEC10A and ASGPR-1, respectively. EGTA (1 mM) was added to the final concentrations indicated to assays. Retention of bound CLEC10A was determined by incubation with biotinylated anti-CLEC10A (goat IgG, R\&D Systems) and detection with streptavidin-peroxidase conjugate (blue). Similar data were obtained in 3 experiments. $\mathbf{d}$ Binding of svL4 and sv6D to human recombinant CLEC10A and ASGPR-1 as a function of concentration of peptide in the assay. The figure is representative of 4 separate assays. $K_{D}$ values \pm S.D. from reciprocal plots of these data are provided in the text

Removal of $\mathrm{Ca}^{2+}$ from these sites relaxes the structure of the binding site and causes loss of sugar-binding activity without significant change in the remainder of the protein. Thus we reasoned that whether the peptides bind to these receptors at the sugar-binding site could be ascertained by chelation of $\mathrm{Ca}^{2+}$. Indeed, binding of the peptides was completely inhibited by chelation of $\mathrm{Ca}^{2+}$ with low concentrations of EGTA (Fig. 3c).

Double-reciprocal plots of binding curves with CLEC10A or ASGPR-1 vs. concentration (Fig. 3d) provided $K_{D}$ values of $0.15 \pm 0.02 \mu \mathrm{M}$ and $0.12 \pm 0.01 \mu \mathrm{M}$, respectively, for sv6D. Corresponding values for binding of svL4 to CLEC10A and ASGPR- 1 of $0.24 \pm 0.04 \mu \mathrm{M}$ and $0.21 \pm 0$. $03 \mu \mathrm{M}$, respectively, were obtained. Although multivalency dramatically increases avidity by decreasing the $\mathrm{k}_{\text {off }}$ rate of binding to receptors $[74,75]$, it has a finite value, which suggests that the equilibrium $K_{D}$ may be slightly elevated because of the extensive wash steps in the assay. Asialofetuin, a multi-glycosylated protein with an $\mathrm{IC}_{50}=45.6 \pm 2$.
$7 \mu \mathrm{M}$ for ASGPR-1 [43], at $75 \mu \mathrm{M}$ inhibited binding of svL4 $(0.2 \mu \mathrm{M})$ to ASGPR-1 by $53 \%$, which is consistent with the determined $\mathrm{K}_{\mathrm{D}}$ value.

\section{Activation of DCs and T cells with peptide}

Binding of a peptide to CLEC10A expressed by DCs is expected to stimulate maturation and potential activation of $\mathrm{T}$ cells [12]. This hypothesis was tested by an experiment in which human monocyte-derived DCs were co-cultured with $\mathrm{T}$ cells. Expression of CLEC10A (CD301) by the DCs was established by flow cytometry (data not shown). sv6D was added to the medium at various concentrations, and IFN- $\gamma$ production by $\mathrm{T}$ cells was assayed. As shown in Fig. $4 \mathrm{a}$, the maximal amount of IFN- $\gamma$ was produced with $10 \mathrm{nM}$ sv6D. Significant release of IFN- $\gamma$ occurred after 3 days of incubation (Fig. 4b), a time required for DC maturation. These results suggest that the optimal concentration of sv6D for an effect on cellular 

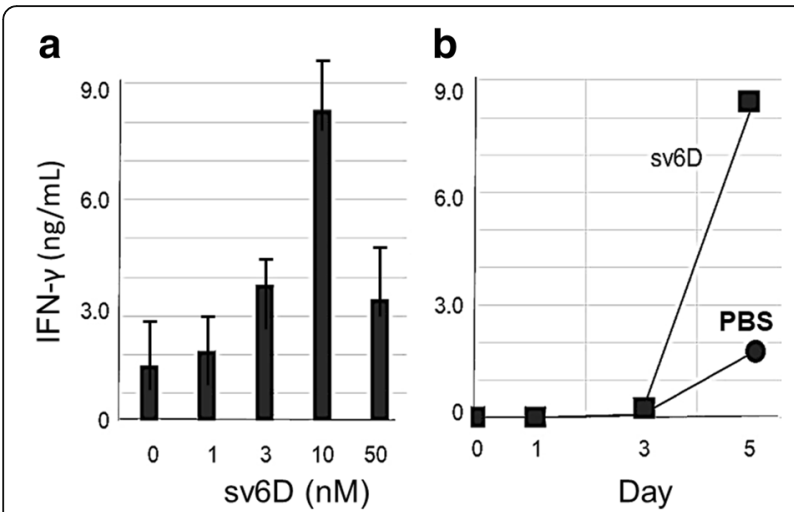

Fig. 4 Mixed leukocyte reaction. An allogenic mixture of $5 \times 10^{3}$ human monocyte-derived immature dendritic cells and $1 \times 10^{5}$ negatively selected $\mathrm{CD}^{+} \mathrm{T}$ cells were incubated with various concentrations of sv6D. a Effect of concentration of sv6D in the medium on release of IFN- $\gamma$ after 5 days of culture. The figure shows results from an experiment with 3 replicates analyzed by one-way ANOVA, which at $10 \mathrm{nM}$ sv6D, $\rho=0.0064$. $\mathbf{b}$ The time course of the appearance of IFN- $\gamma$ in the medium of cultures incubated with $10 \mathrm{nM}$ sv6D in (a)

activity is an order of magnitude lower than the $K_{D}$ obtained from chemical binding assays as in Fig. 3d.

\section{Responses of immune cells in the peritoneal cavity of healthy mice}

To explore their physiological activity in vivo, the peptides were injected subcutaneously into mice. Minimal changes in cell populations were observed in the blood of healthy animals. In contrast, an analysis of total cells in a peritoneal lavage revealed that Balb/c mice contained a large population of small cells (low FSc) with minimal intracellular complexity (low SSc), whereas this population of cells was minimal in C57BL/6 mice (Additional file 1: Figure S1). These observations confirm the results of Festing et al. [76] that peritoneal cells in Balb/c mice expressed a high 'lymphocyte' to 'macrophage' ratio whereas the reverse occurs in C57BL strains. Within $24 \mathrm{~h}$ after injection of peptide, the population of small cells largely disappeared in Balb/c mice but increased in C57BL/6 mice (Additional file 1: Figure S1). Attempts to identify these cells suggested that they comprise a myeloid progenitor population whose proliferation is highly responsive to treatment with the peptide (Additional file 2: Figure S2).

To examine whether increases occurred in mature immune cells, peritoneal cells from Balb/c and C57BL/6 mice were analyzed by flow cytometry after cells were stained with the markers listed in Table 2. Several-fold increases in macrophages, DCs, $\mathrm{T}$ cells and natural killer (NK) cells were found $24 \mathrm{~h}$ after a single injection of svL4 ( $1 \mathrm{nmole} / \mathrm{g}$ ) into Balb/c mice but a significant increase occurred only after the second injection into C57BL/6 mice. To explore this observation more extensively, svL4 or
sv6D was injected into C57BL/6 mice on day 0, 2 or 4 . Peritoneal cells were examined by flow cytometry $24 \mathrm{~h}$ after each injection. Shown in Fig. 5 are results expressed as cell counts for F4/80 CD11b CD86 (mature, active macrophages); CD11c (DCs); CD11c CD 86 (activated DCs); CD4 CD69 (activated T cells); CD8 CD69 (activated cytotoxic T cells); NK1.1 CD3 ${ }^{+}$CD69 (activated NKT cells); NK1.1 CD3- CD69 (activated NK cells); CD19 (B cells); and CD19 CD73 CD80 CD273 (memory B cells). The numbers of these mature, activated cells continued to increase with each injection. Overall, the responses to sv6D were greater than those to svL4, with large increases in DCs $\left(\mathrm{CD}_{11 \mathrm{c}^{+}}\right.$and $\left.\mathrm{CD} 11 \mathrm{c}^{+} \mathrm{CD}^{+} 6^{+}\right), \mathrm{T}$ cells $\left(\mathrm{CD}^{+}\right.$, $\mathrm{CD}^{+}$and $\left.\mathrm{CD}^{+}\right)$and NKT cells $\left(\mathrm{NK} 1.1, \mathrm{CD}^{+}\right)$, although $\mathrm{CD} 19^{+} \mathrm{B}$ cells responded more strongly to svL4. The mean fluorescence intensity did not change significantly, which suggested that the peptides promoted an expansion of mature cell populations. As a control, the expansion of peritoneal cell populations induced by svL 4 and sv6D was compared with that of svC1, which as shown in Fig. 2a does not bind to CLEC10A. Populations of specific cell types from animals treated with svC1 did not increase significantly over the 5 -day period.

To determine whether the target(s) for svL4 is located on lymphocytes, with subsequent cross-talk signaling to achieve activation of monocytes, an experiment was performed in which svL4 was injected into $\mathrm{RAG}^{-1-}$ mice, which lack activity of $\mathrm{rag}$, the recombination activation gene. The ability to perform recombination to generate antigen-specific antibodies by $\mathrm{V}(\mathrm{D}) \mathrm{J}$ recombination is required for $\mathrm{B}$ and $\mathrm{T}$ cell precursors to produce functional antigen receptors on their surface, and without a functional rag gene these cells undergo apoptosis [77]. The response of monocytes in the peritoneal cavity of $\mathrm{RAG}^{-1-}$ mice to treatment with svL4 was essentially the same as that in C57BL/6 mice (data not shown). The deficiency of $\mathrm{B}$ and $\mathrm{T}$ cells did not reduce the maturation of monocytes, which suggested that svL4 acts on targets within the myeloid lineage.

\section{Efficacy of peptides in murine model of ovarian cancer}

The strong responses of the peritoneal immune cells to the peptides led us to test whether they would be effective in treating cancers of peritoneal organs. A murine ovarian cancer cell line (ID8) was implanted into the peritoneal cavity of C57BL/ 6 female mice on day 0 . In this system, tumor progression in the peritoneal cavity is initially slow but then progresses rapidly, with ultimate accumulation of ascites [51]. Treatment with sv6D routinely began 45 days after implantation when macroscopic tumor seeds were present, which is analogous to the stage at which most women are diagnosed [78, 79]. Progression of the cancer was monitored by body weight of animals as an indication of ascites accumulation. 


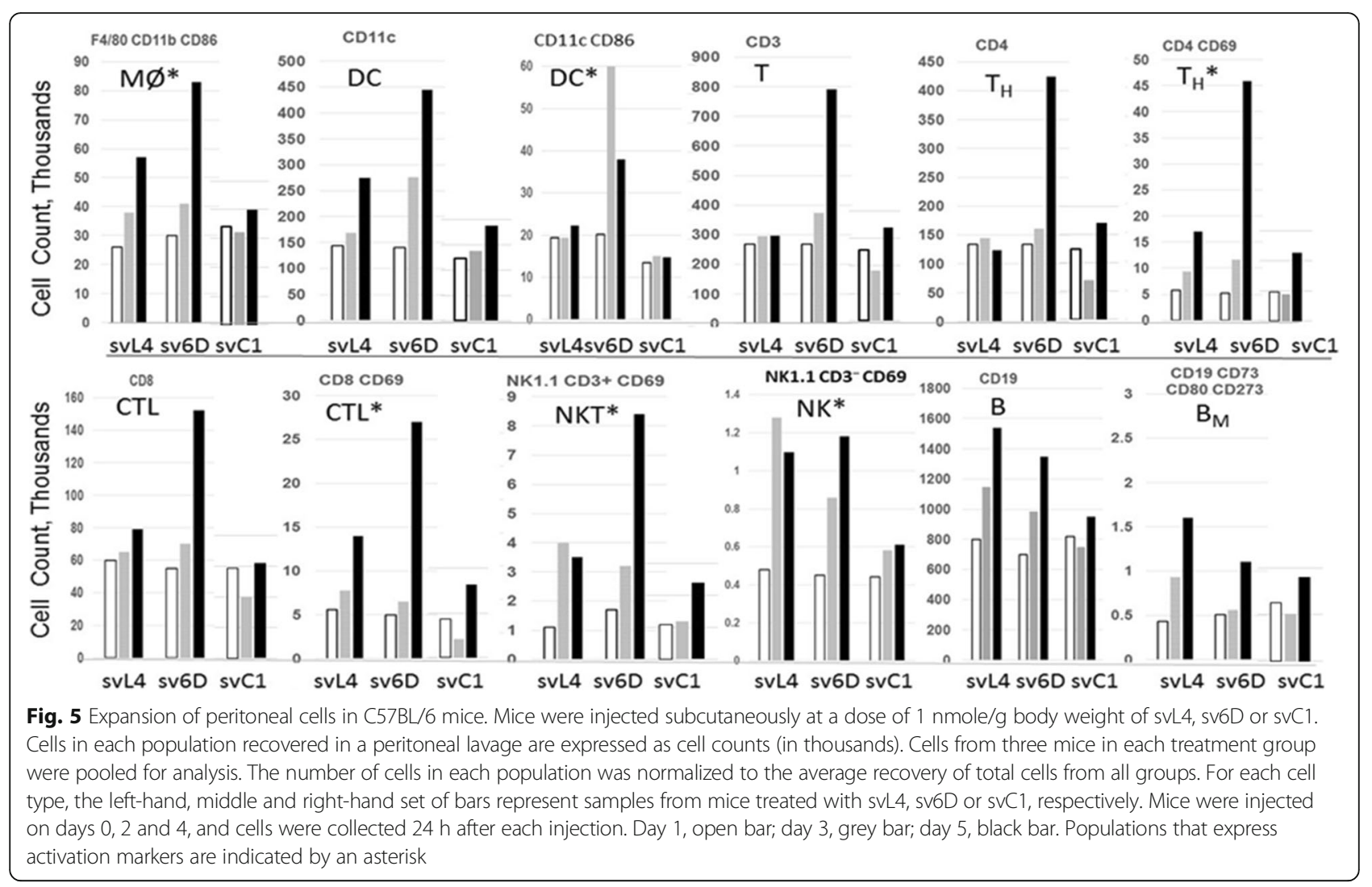

Efficacy of sv6D was compared with that of paclitaxel, a standard-of-care chemotherapeutic drug that stabilizes microtubules, interferes with the function of kinetochores, and arrests cells at the G2/M boundary of mitosis $[80,81]$. In the experiment illustrated in Fig. 6a, progression of disease was aggressive and evidence of ascites accumulation was observed already at day 45 , the time treatment was initiated. After two weeks of treatment, when disease in several control mice had already progressed to end stage, weights of mice treated with sv6D at a dose of $0.1 \mathrm{nmole} / \mathrm{g}$ body weight or paclitaxel had not significantly increased. This observation suggested that treatment with sv6D suppressed accumulation of ascites when first evident.

We then asked whether sv6D would be effective in combination with paclitaxel. In this study the disease progressed more slowly, with the median end-stage at day 122. sv6D again suppressed accumulation of ascites when treatment was initiated at day 45 , with no significant weight gain for half the animals at day 120 (Fig. 6b). Efficacy of sv6D at a dose of $0.1 \mathrm{nmole} / \mathrm{g}$ was comparable to that of paclitaxel, with median survival of approximately 141 days (Fig. 6c). Because cancer cells eventually escape paclitaxel treatment, these results led to initiation of treatment with sv6D at day 100, 50 days after treatment with paclitaxel, when accumulation of ascites was first observed in this group. Over the next 3 weeks, alternate-day injections of sv6D completely suppressed further increases in weight of the animals (Fig. 6b). Continued treatment with sv6D resulted in dramatic extension of survival of the animals to a median of 169 days (Fig. 6c).

\section{Efficacy of sv6D in combination with anti-PD-1}

Intraperitoneal injection of a monoclonal anti-mouse PD-1 is modestly effective in mice with ovarian cancer model $[82,83]$. We tested whether sv6D would extend effectiveness of anti-PD-1. Five doses of anti-PD-1 (200 $\mu \mathrm{g}$ in PBS) were injected intraperitoneally on alternate days between days 41 and 49. sv6D was injected subcutaneously immediately after the treatment with anti-PD-1 and continued on alternate days to the end of the study (Fig. 7a, group 3). When administration of sv6D to a group that had been treated with anti-PD-1 was delayed until day 87, after weight of the animals began to increase (group 5), essentially complete suppression of ascites formation was sustained for several weeks. Group 6, with a hiatus of one week after a week of treatment, survived only slightly longer than animals treated with PBS. This observation appears similar to the unresponsiveness of $\mathrm{T}$ cells that was observed in mice within a week after treatment with antibodies against C-type lectin receptors on DCs [12, 84]. For comparison, survival of animals with continuous alternateday injection of sv6D alone, from the experiment shown in Fig. 6c, is included as group 7. The median survival of 


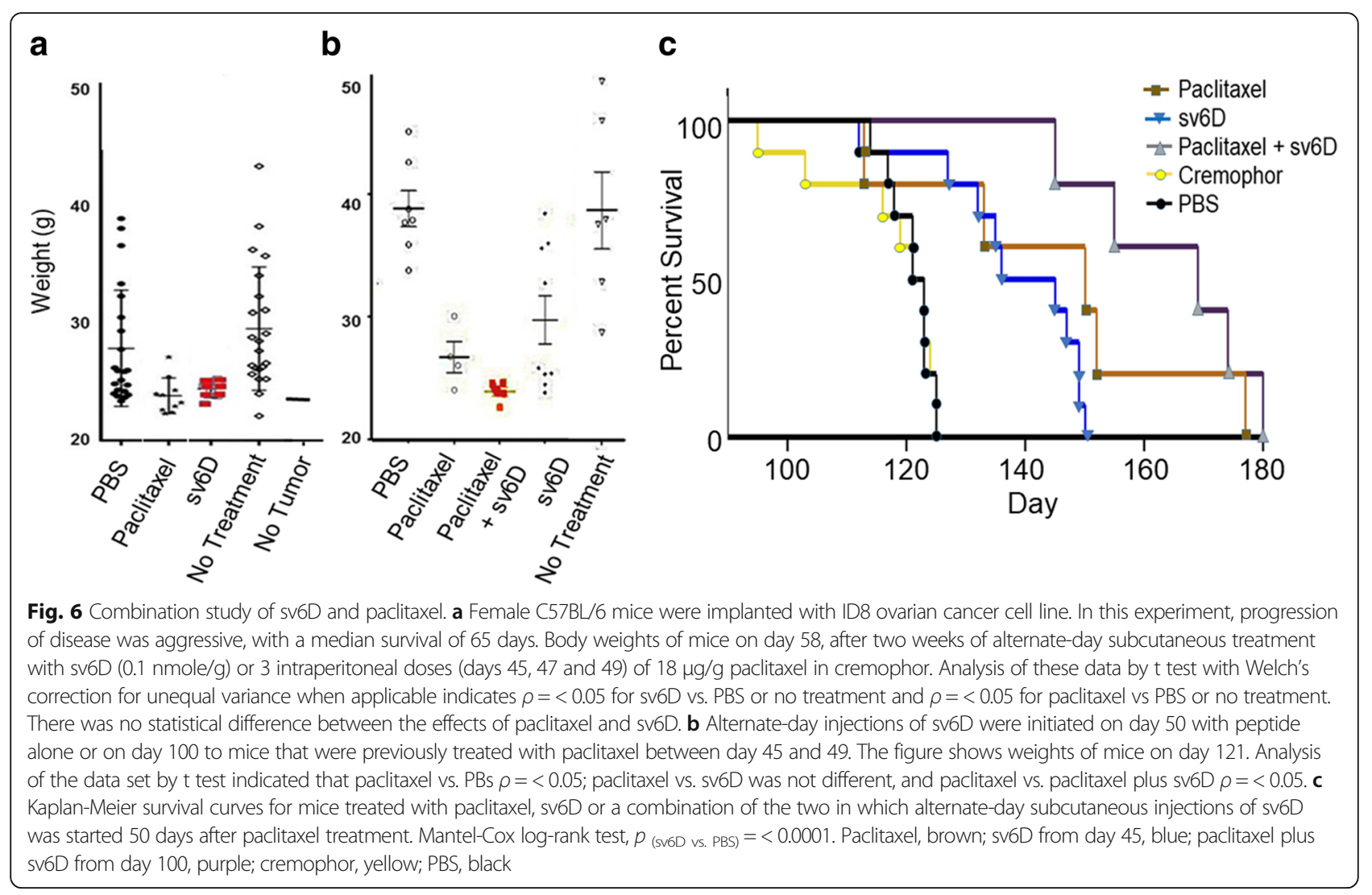

control groups treated with PBS in both experiments was the same (122 days). Kaplan-Meier survival curves are shown in Fig. 7b.

\section{Toxicity of peptide treatment}

Although weight gain is a good measure of disease progression in this model of disseminated ovarian cancer in the peritoneal cavity, consideration of mean group weight is complex. Because this is an intact biological model, inherent variation exists. As disease in individual animals within a treatment group progress, the variation in weight within the treatment group increases. When an individual animal reaches end-stage disease and is euthanized, the mean group weight may drop and the variation within the group decreases. Given this complexity, there remained several instances in which reduced progression of disease within a treatment group was reflected in differences in weight that reached statistical significance.

It is important to note that during and after drug administration there was no change in mouse behavior, indicating no overt toxicity related to peptide treatment. Further, repeated injection of peptide in the same region resulted in no apparent irritation or formation of fibrous or granulomatous tissue. Attempts to detect antibodies that bind the peptides in sera from mice injected on alternate days for 3 months with 1 nmole/g svL4 or sv6D were negative (Fig. 8), which indicated that the peptides are not antigenic in mice.

To determine whether the peptides induced a significant release of cytotoxic cytokines, sera were collected from female Balb/c mice into which breast cancer 4 T1 cells had been implanted. After the tumors had grown over a period of 10 to 12 days to a size of $\sim 500 \mathrm{~mm}^{3}$, svL4 was injected subcutaneously at doses of 0.1 or 1.0 nmole/g. Sera were prepared $4 \mathrm{~h}$ after injection and analyzed with an array of 308 cytokines/chemokines (see Additional file 3: Figure S3). Ratios of the amounts of selected cytokines from treated vs. untreated mice are listed in Table 3.

Several cytokines had negligible values in untreated mice, and thus the ratio of treated (although low) vs. untreated animals had a high value. Ratios of treated vs. untreated samples obtained in a separate experiment with healthy Balb/c mice are shown in the right-hand column of Table 3 for comparison. The most significant increase in the serum of healthy mice treated with the peptide was in the amount of soluble HVEM (Herpes virus entry mediator, also designated TNFRSF14), which was a prominent protein in serum and increased approximately 10 -fold within $4 \mathrm{~h}$ after treatment. In the tumor-bearing mice, the level of soluble HVEM in treated animals was similar to that in treated healthy 

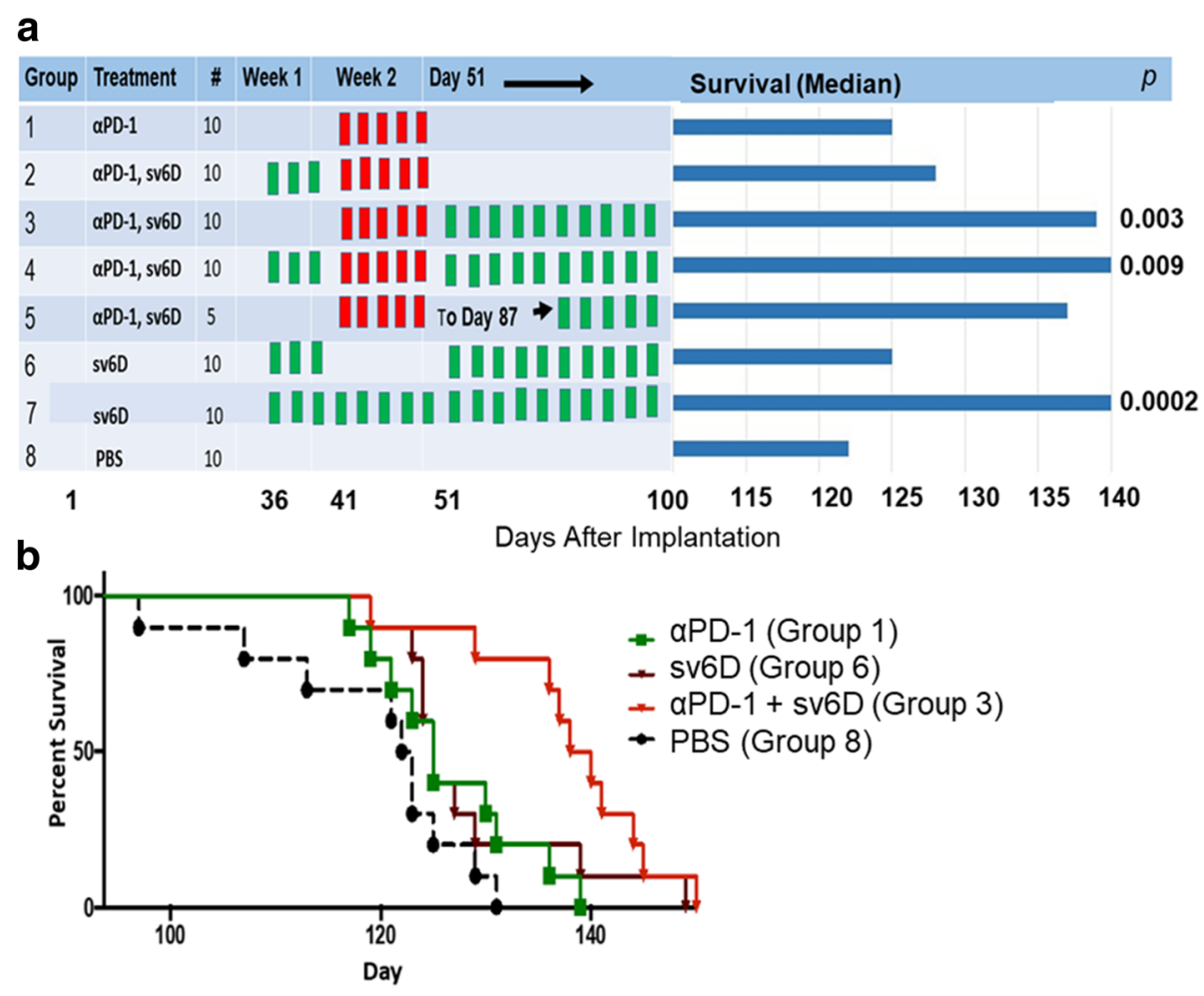

Fig. 7 Combination study of sv6D and anti-PD-1. a The design of the experiment and extension of survival of C57BL/6 female mice implanted with ovarian cancer cell line ID8 and treatments with anti-PD-1 and sv6D. Anti-PD-1 (rat anti-mouse, clone 29F.1A12) was administered intraperitoneally every other day, $200 \mathrm{\mu g}$ protein per dose, between day 41 and 49 (red bars). sv6D was administered subcutaneously every other day at $0.1 \mathrm{nmole} / \mathrm{g}$, starting on day 36,51 or 87 (green bars). Survival data were analyzed by the Mantel-Cox log-rank test to determine $\rho$ values. b Kaplan-Meier survival curves of mice treated with anti-PD-1 and/or sv6D. The figure shows survival of groups 1, 3, 6 and 8. For group 3, the Mantel-Cox log-rank test $p=$ 0.003 indicates the significance between treatment with the combination and antibody alone. Anti-PD-1, green; SV6D, brown; anti-PD-1 followed by sv6D (Group 3 in a), red; PBS, black

mice, but the level in untreated animals was higher than that in healthy control mice. Interestingly, cytokines that were strongly elevated in mice bearing tumors were often reduced in healthy mice in response to svL4 or showed no change. The amounts of inflammatory cytokines in the sera did not appear to reach toxic levels.

\section{Discussion}

Peptides are uniquely suited to immunotherapy. Peptides are flexible in design, easily synthesized on a large scale, water soluble, and relatively stable. Although their use as vaccines has a long and successful history, peptides have also been designed that bind selectively to lectin-type receptors with high avidity ([85-87] and references therein). Their use in receptor-mediated immunotherapy is based on their ability to bind to regulatory, lectin-type, cellsurface receptors expressed by cells of the immune system, with avidities that are orders-of-magnitude greater than endogenous ligands. The interaction of multivalent ligands with multimeric receptors leads to dramatic increases in binding avidity, which decrease the concentration for half-maximal binding to the low nanomolar range. Therefore, peptides such as svL4 and sv6D, described in this report as mimetics of GalNAc, provide a means to modulate activity of immune cells. As shown in Fig. 5, the peptides promote a broad expansion of immune cell populations in the peritoneal cavity. Furthermore, long-term treatment did not induce production of antibodies in the mouse (Fig. 8).

To explore whether targeting $\mathrm{C}$-type $\left(\mathrm{Ca}^{2+}\right.$-dependent $)$ lectin-type receptors offers a novel immunotherapeutic approach to cancer treatment, our research focused on CLEC10A (CD301) that is expressed by several cell types at strategic stages in the immune pathway, whose activation can lead to immune responses and a good therapeutic outcome [12]. CLEC10A expression is upregulated during differentiation of myeloid committed progenitor cells [88]. Possibly, peptide binding to these cells induces proliferation of cells that differentiate into mature, activated immune cells in the peritoneal cavity (see Additional file 4: Supplemental Material). Our data support the hypothesis that the peptides svL4 and sv6D engage CLEC10A on dermal DCs and immature peripheral DCs and promote cellular maturation. Interaction of $\mathrm{T}$ cells with mature $\mathrm{DCs}$ within 


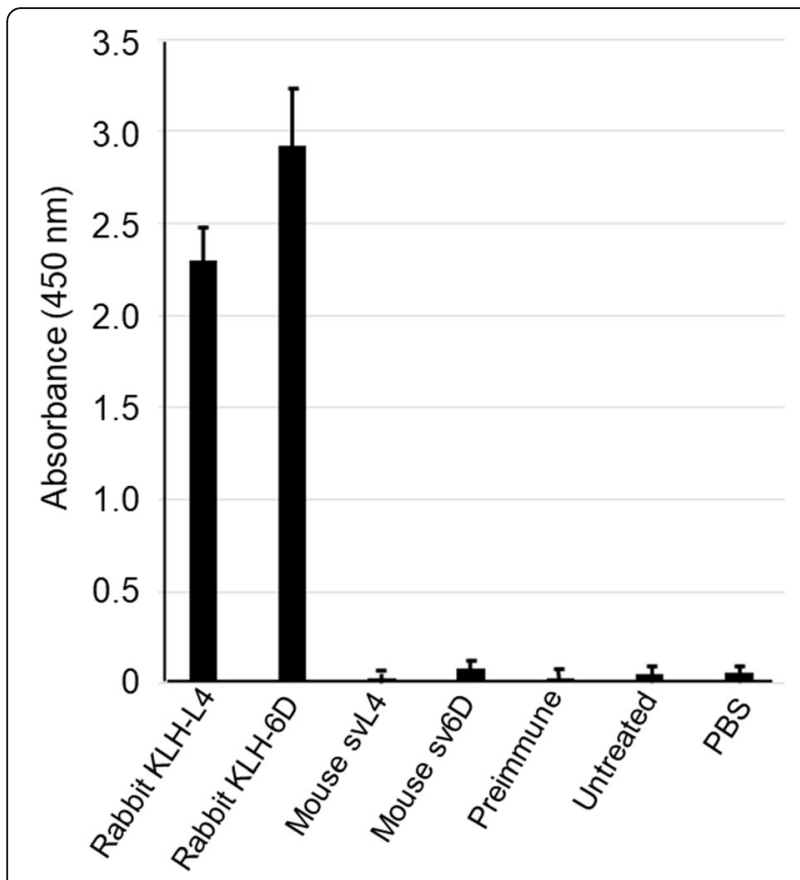

Fig. 8 Test for antigenicity of svL4 and sv6D. Anti-sera were generated in rabbits against KLH-conjugates of the sequences of sVL 4 or SV6D and diluted 1:10. Mouse sera were collected after alternate-day injections of svL4 over 3 months, diluted 1:1 with PBS and added to protein-A/Gcoated wells. Biotinylated SVL4 or SV6D was added to wells and bound peptide was detected with a streptavidin-peroxidase conjugate. The figure includes values \pm S.D. for sera from 8 treated mice in each group assayed separately lymphoid tissues leads to their activation. DCs are integral to regulation of the immune system through multidirectional and reciprocal cross-talk, which leads to activation of other types of cells such as NK cells to support innate immunity $[89,90]$.

Alternatively-activated, tumor-associated macrophages, in particular the classical immunosuppressive M2a type, express CLEC10A [91]. Activation of the phagocytic activity of macrophages leads to reduction of $\mathrm{T}_{\mathrm{REG}}$ cells in melanoma tumors $[92,93]$. Preliminary results showed that treatment of melanoma-bearing mice with svL4 caused a dramatic reduction in $\mathrm{T}_{\mathrm{REG}}$ cells within tumors (data not shown), which possibly resulted from nudging M2a cells to the more phagocytic M2b macrophages by engaging CLEC10A. Of importance for this study, CLEC10A is expressed by DCs in skin and peripheral immature DCs. Ligand binding to the receptor initiates maturation and migration of DCs to lymphoid tissues, where they engage in antigen presentation to T cells [34-36]. Targeting MGL2 on dermal DCs with a multivalent Tn antigen induced a potent MHC II-restricted $\mathrm{T}$ cell response and release of Th2 cytokines such as IL-4, IL-5, IL-10 and IL-13 in Balb/c mice [24].

An analysis of lectin-type receptors on human blood DCs and the extent of binding of an array of glycans revealed that prominent among the glycans that bound were those with terminal GalNAc residues [94]. This study by Rapoport et al. was performed to evaluate optimal vectors for delivering vaccines to DCs and concluded from these results that MGL (CLEC10A) is a promising target.

Table 3 Ratios of the levels of selected cytokines in sera from treated vs. untreated animals

\begin{tabular}{|c|c|c|c|}
\hline Cytokine & Tumor-bearing & Expression & Healthy \\
\hline $\mathrm{IL}-1 \mathrm{a}$ & 2.7 & Activated Macrophages & 0.86 \\
\hline$\| \mathrm{L}-12 \mathrm{p} 70$ & 3.5 & Dendritic cells and macrophages & No change \\
\hline $\mathrm{IL}-16$ & 4 & Released by lymphocytes & 0.57 \\
\hline $\mid \mathrm{L}-27$ & 4.5 & Antigen-presenting cells, promotes Th1 responses & 0.55 \\
\hline IL-28 & 4.3 & Augments IFN- $\gamma$ release, cytotoxic potential of $\mathrm{CD}^{+} \mathrm{T}$ cells & High* $^{*}$ \\
\hline IL-31 & 3.5 & Activated Th2 T cells & $\mathrm{High}^{*}$ \\
\hline $\mathrm{MIP}-2 / \mathrm{CXCL} 2$ & $\sim 6$ & Secreted by monocytes and macrophages & No change \\
\hline Pentraxin3 & $\sim 4$ & Mononuclear phagocytes, dendritic cells and neutrophils & 0.21 \\
\hline SPARC & $\sim 5$ & Osteoblasts, macrophages at site of wound repair & No change \\
\hline TIMP-2 & 3 & Metastasis suppressor, expressed by monocytes, placenta & 0.45 \\
\hline TNFa & $45^{*}$ & Activated monocytes and macrophages & 0.21 \\
\hline TLR2 & 4.2 & Activated monocytes, DCs, macrophages, B and T cells & 0.37 \\
\hline Lymphotoxin-a & $12.5^{*}$ & Produced by Th1 T cells & 0.74 \\
\hline sHVEM & $\sim 2$ & Activated monocytes and lymphocytes & 10 \\
\hline IFN- $\gamma$ & $\operatorname{High}^{*}$ & Activated lymphocytes & No change \\
\hline CCL1 & 2.5 & Activated T cells & No change \\
\hline Lymphotactin & $\sim 3$ & Activated $\mathrm{CD}^{+}$cells & 2.6 \\
\hline
\end{tabular}

Markers of lymphocyte and monocyte activation in response to $0.1 \mathrm{nmole} / \mathrm{g}$ svL4 in Balb/c mice bearing breast tumors are compared with healthy mice. Sera from three animals were pooled for analysis with an array of 308 soluble factors. (*In these samples, the control value was negligible or low, thus the fold increase for treated samples appears high) 
However, $\mathrm{IC}_{50}$ for binding glycan-PAA conjugates was about $20 \mu \mathrm{M}$ [94]. Multivalent peptides such as sv6D achieve an optimal cellular response with concentrations near $10 \mathrm{nM}$ (Fig. 4) and preliminary data show that sv6D effectively activates $T$ cells against an antigen in vivo (data not shown).

The highly glycosylated, cell membrane protein CD45, which bears the Tn structure at positions 137 and 140 in exon B of the sequence [22], was identified as an endogenous ligand of CLEC10A/MGL [95]. Although the Tn antigen binds to the receptor with much lower avidity than the peptides svL4 and sv6D [32], and the affinity of an intact glycoprotein bearing a single sugar $\left(K_{I} \approx 23 \mu M[96]\right)$ is several orders of magnitude less than that of the peptides, these structures are conceivably competitive inhibitors. CD45 is expressed as several isoforms, with the full length protein containing exons $\mathrm{A}, \mathrm{B}$ and $\mathrm{C}$ at the extracellular, variable region [97, 98]. Binding of CLEC10A to exon B-containing isoforms causes attenuation of $\mathrm{T}$ cell activity, apoptosis and immunosuppression [95]. However, activation of $\mathrm{T}$ cells leads to expression of shorter isoforms of CD45 such as CD45RO and CD45RA that lack exon B [99-102]. Moreover, maturation of DCs leads to down-regulation of CLEC10A [95], which would minimize inhibition by CD45 of $\mathrm{T}$ cell activation during treatment with the peptides.

Paclitaxel is currently used as a chemotherapeutic drug that acts by stabilizing microtubules and arresting cells in the cell cycle at the G2/M boundary [80, 81]. Paclitaxel is often combined with a platinum-based drug $[103,104]$. Patients treated with these drugs experience a significant level of toxicity. Our data suggest that sv6D would serve as an effective combination drug without adding toxicity. However, because sv6D induces proliferation of immune cells, initiation of treatment should perhaps occur after the cell cycle inhibitory action of paclitaxel has dissipated [105]. Patients with ovarian cancer have a $15 \%$ overall response rate during treatment with antibodies against the inhibitory receptor PD-1 (pembroliumab or nivolumab in human therapy) [106, 107]. The antibodies exhibit modest effectiveness in mouse models $[82,83]$. The peptide sv6D inhibited accumulation of ascites to a greater extent than anti-PD-1 and also was effective in combination with the antibody. Particularly interesting is the effectiveness of sv6D when administration was delayed following anti-PD-1 (Fig. 7). Our peptide drugs satisfy the criteria described by Hamanishi et al. [108], who concluded that "particularly important in ovarian cancer, (which) is not associated with a high response rate, anti-cancer treatments are considered to be excellent if they are associated with low medical costs, low toxicity and high 'benefits' (antitumor response)."

\section{Conclusion}

Our data support the hypothesis that GalNAc-specific lectins such as CLEC10A, expressed by DCs in the skin and immature DCs and macrophages, are target(s) for the peptides svL4 and sv6D. Extensive evidence supports initiation of a $\mathrm{Ca}^{2+}$ signal upon ligand-induced endocytosis of such $\mathrm{Ca}^{2+}$-dependent receptors [12]. Subsequent maturation of DCs leads to activation of T cells and other immune cells by cross-talk [90]. The result is a broad stimulation of the immune system that, although not antigen specific, is adaptable to various cancers and infectious diseases. sv6D possibly can be used as a monotherapy, and the lack of apparent toxicity also offers the potential that expansion of immune cell populations by the peptides may be a foundational treatment upon which combination immuno-therapies can be built. Although our data thus far support binding of svL4 and sv6D to lectins specific for GalNAc, it is possible that the peptides may also bind to other receptors not assayed in this study. The full extent of the activities of peptides svL4 and sv6D must await further research.

\section{Additional files}

Additional file 1: Figure S1. Pseudocolor scatter plots of SSC vs. FSC from flow cytometric analyses of peritoneal cells from healthy (a) C57BL/6 or (b) Balb/c mice $24 \mathrm{~h}$ after injection with various doses of svL4. The population of small cells is circled. Graphical presentations of duplicate measurements of this population are expressed as a percent of total events. Peritoneal cells from 2 animals were pooled for each analysis. (TIFF $1300 \mathrm{~kb}$ )

Additional file 2: Figure S2. Increase in the population of small cells in the peritoneal cavity of Balb/c mice bearing tumors of breast 4T1 cancer cell line. svL4 (1 nmole/g) was injected on day 0 and day 2 , with analysis $24 \mathrm{~h}$ after each injection. a) Pseudocolor scatter plots of peritoneal cells from untreated or treated mice on day 3,24 h after the second injection. The low SSc and low FSc population is circled. b) The bar graph shows the low SSc and low FSc population presented as percent of total cells from analyses at days 1 and 3 . Untreated animals, blue; treated animals, orange. Peritoneal cells from 3 animals were pooled and analyzed in triplicate. c) Histograms of normalized SSc vs. FSc for samples of peritoneal cells from Balb/c mice on day 3, from Fig. S2b, i.e., 24 h after the second injection of sVL4. Blue trace, untreated animals; red trace, svL4-treated animals. (TIFF $1985 \mathrm{~kb}$ )

Additional file 3: Figure S3. Cytokines/chemokines in the sera of 4T1 tumor-bearing Balb/c mice treated with $\mathrm{sVL} 4$ at doses of $0.1 \mathrm{nmole} / \mathrm{g}$ (orange) or $1 \mathrm{nmole} / \mathrm{g}$ (grey) body weight as compared with samples from animals injected with PBS (blue) $4 \mathrm{~h}$ after subcutaneous injections. Note: TNF- $\beta$ is the same as lymphotoxin-a. Values indicate relative densities of dots on the mouse L-308 membrane array as analyzed by RayBiotech, Inc. (Norcross, GA). (PPTX 541 kb)

Additional file 4: Supplemental Material. (DOCX $28 \mathrm{~kb}$ )

\section{Abbreviations}

ASGPR-1: asialoglycoprotein receptor-1; CLEC10A: calcium-dependent lectin-type receptor family member 10A; CRD: carbohydrate recognition domain; DCs: dendritic cells; DC-SIGN: dendritic-cell specific intercellular adhesion molecule (ICAM)-3 grabbing non-integrin; Gal: galactose; GalNAc: N-acetylgalactosamine; GalNAc-PAA: GalNAc conjugated to polyacrylamde; KLH: keyhole limpet hemocyanin; NQHTPR: AsparagineGlutamine-Histidine-Threonine-Proline-Arginine; RMSD: root-mean-square deviation; S.D.: standard deviation 


\section{Funding}

The work was supported by Susavion Biosciences, Inc.

\section{Availability of data and materials}

All data generated and analyzed during this study are included within this published article and its supplementary information files.

\section{Authors' contributions}

LLE and JKH designed and performed biochemical and cell biology experiments. KFR performed the ovarian cancer studies. RC performed computer modeling and literature searches. JKH wrote the manuscript and all authors read, edited and approved the version for submission.

\section{Ethics approval and consent to participate}

Studies with commercially available human cells were conducted by Astarte Biologics, Inc., according to Institutional Review Board (IRB) approved protocols that are reviewed on an annual basis Studies with mice were conducted according to approved protocols by Biomodels LLC (IACUC approval number 13-0611-01) and at the University of Kansas Medical Center (IACUC approval number 2015-2288).

\section{Consent for publication}

Not applicable.

\section{Competing interests}

LLE and JKH declare that they are inventors of the technology contained in this report. Intellectual property that has been assigned to Susavion Biosciences, Inc., in which these authors hold shares. Other authors have no conflicts of interest to report.

\section{Publisher's Note}

Springer Nature remains neutral with regard to jurisdictional claims in published maps and institutional affiliations.

\section{Author details}

'Susavion Biosciences, Inc., 1615 W. University Drive, Suite 132, Tempe, AZ 85281, USA. ${ }^{2}$ University of Kansas Medical Center, Kansas City, Kansas, USA.

\section{Received: 20 February 2018 Accepted: 3 April 2018 \\ Published online: 17 April 2018}

\section{References}

1. van Kooyk Y, llarregui JM, van Vliet SJ. Novel insights into the immunomodulatory role of the dendritic cell and macrophage-expressed Ctype lectin MGL. Immunobiology. 2015;220:185-92. PMID: 25454488

2. Zizzari IG, Napoletano C, Battisti F, Rahimi H, Caponnetto S, Pierelli L, Nuti M, Rughetti A. MGL receptor and immunity: when the ligand can make the difference. J Immunol Res. 2015;article 450695:doi.org/10.1155/2015/450695. PMID: 26839900

3. Yan H, Kamiya T, Suabjakyong P, Tsuji NM. Targeting C-type lectin receptors for cancer immunity. Front Immunol. 2015;6:408. https://doi.org/10.3389/ fimmu.2015.00408. PMID: 26379663

4. Drickamer K, Taylor ME. Recent insights into structures and functions of Ctype lectins in the immune system. Curr Opin Struct Biol. 2015;34:26-34. PMID: 26163333

5. Ng KK-S, Park-Snyder S, Weis WI. Ca ${ }^{2+}$-dependent structural changes in C-type mannose-binding proteins. Biochemistry. 1998;37:17965-76. PMID: 9922165

6. Feinberg H, Park-Snyder S, Kolatkar AR, Heise CT, Taylor ME, Weis WI. Structure of a C-type carbohydrate recognition domain from the macrophage mannose receptor. J Biol Chem. 2000;275:21539-48. PMID: 9922165

7. Meier M, Bider MD, Malashkevich VN, Spiess M, Burkhard P. Crystal structure of the carbohydrate recognition domain of the $\mathrm{H} 1$ subunit of the asialoglycoprotein receptor. J Mol Biol. 2000;300:857-65. PMID: 10891274

8. Higashi N, Fujioka K, Denda-Nagai, Hashimoto S, Nagai S, Sato T, et al. The macrophage C-type lectin specific for galactose/N-acetylgalactosamine is an endocytic receptor expressed on monocyte-derived immature dendritic cells. J Biol Chem. 2002;277:20686-93. PMID: 11919201

9. van Vliet SJ, Saeland E, van Kooyk Y. Sweet preferences of MGL: carbohydrate specificity and function. Trends Immunol. 2008;29:83-90. PMID: 18249034
10. Vukman KV, Ravidà A, Aldridge AM, O'Neill SM. Mannose receptor and macrophage galactose-type lectin are involved in Bordetella pertussis mast cell interaction. J Leukoc Biol. 2013;94:439-48. PMID: 23794711

11. Wong KL, Yeap WH, Tai JJY, et al. The three human monocyte subsets: implications for health and disease. Immunol Res. 2012;53:41-57. PMID: 22430559

12. Cote R, Eggink LL, Hoober JK. CLEC receptors, endocytosis and calcium signaling. AIMS Allerg Immunol. 2017;1:207-31. https://doi.org/10.3934/ Allergy.2017.4.207

13. Morgan AJ, Platt FM, Lloyd-Evans E, Galione A. Molecular mechanisms of endolysosomal $\mathrm{Ca}^{2+}$ signaling in health and disease. Biochem J. 2011;439: 349-74. PMID: 21992097

14. Plattner $\mathrm{H}$, Verkhratsky A. Inseparable tandem: evolution chooses ATP and $\mathrm{Ca}^{2+}$ to control life, death and cellular signaling. Phil Trans R Soc B. 2016; 371:20150419. PMID: 27377729

15. Carafoli E, Krebs J. Why calcium? How calcium became the best communicator. J Biol Chem. 2016:291:20849-57. PMID: 27462077

16. Faries MB, Bedrosian I. Xu S, Koski G, Roros JG, Moise MA, et al. Calcium signaling inhibits interleukin-12 production and activates CD83 dendritic cells that induce Th2 development. Blood. 2001;98:2489-97. PMID: 11588047

17. Shumilina E, Huber SM, Lang F. Ca ${ }^{2+}$ signaling in the regulation of dendritic cell functions. Am J Physiol Cell Physiol. 2011:300:C1205-14. PMID: 21451105

18. Anstee DJ. The relationship between blood groups and disease. Blood. 2010;115:4635-43. PMID: 20308598

19. Schjoldager KTBG, Clausen H. Site-specific protein O-glycosylation modulates preprotein processing-deciphering specific functions of the large polypeptide GalNAc-transferase gene family. Biochim Biophys Acta. 2012;1820:2079-94. PMID: 23022508

20. Perez-Vilar J, Hill RL. The structure and assembly of secreted mucins. J Biol Chem. 1999;274:31751-4. PMID: 10542193

21. Pinho SS, Reis CA. Glycosylation in cancer: mechanisms and clinical implications. Nat Rev Cancer. 2015;15:540-55. PMID: 26289314

22. Zheng J, Xiao H, Specific WR. identification of glycoproteins bearing the Tn antigen in human cells. Angew Chem Int Ed Engl. 2017;56:7107-11. PMID: 28514044

23. Singhal A, Fohn M, Hakomori S-I. Induction of a-N-acetylgalactosamine-Oserine/threonine ( $\mathrm{Tn})$ antigen-mediated cellular immune response for active immunotherapy in mice. Cancer Res. 1991;51:1406-11. PMID: 1997178

24. Freire T, Zhang X, Dériaud E, Ganneau C, Vichier-Guerre S, Azria E, et al. Glycosidic Tn-based vaccines targeting dermal dendritic cells favor germinal center B-cell development and potent antibody response in the absence of adjuvant. Blood. 2010;116:3526-36. PMID: 20720186

25. Freire T, Lo-Man R, Bay S, Leclerc C. Tn glycosylation of the MUC6 protein modulates its immunogenicity and promotes the induction of Th17-biased T cell responses. J Biol Chem. 2011;286:7797-811. PMID: 21193402

26. Madsen CB, Petersen C, Lavrsen K, Harndahl M, Buus, Clausen H, Pedersen $\mathrm{AE}$, Wandall HH. Cancer associated aberrant protein O-glycosylation can modify antigen processing and immune response. PLoS One. 2012;7(11): e50139. https://doi.org/10.1371/journal.pone.0050139. PMID: 23189185

27. Liu S-Y, Shun C-T, Hung K-Y, Juan H-F, Hsu C-L, Huang M-C, I-Rue L. Mucin glycosylating enzyme GALNT2 suppresses malignancy in gastric adenocarcinoma by reducing MET phosphorylation. Oncotarget. 2016;7: 11251-61. PMID: 26848976

28. Napoletano C, Rughetti A, Agervig Tarp MP, Coleman J, Bennett EP, Picco G, et al. Tumor-associated Tn-MUC1 glycoform is internalized through the macrophage galactose-type C-type lectin and delivered to the HLA class I and II compartments in dendritic cells. Cancer Res. 2007;67:8358-67. PMID: 17804752

29. Irazoqui F, Sendra VG, Lardone RD, Nores GA. Immune response to Thomsen-Friedenreich disaccharide and glycan engineering. Immunol Cell Biol. 2005;83:405-12. PMID: 16033536

30. Chia J, Goh G, Bard F. Short O-GalNAc glycans: regulation and role in tumor development and clinical perspectives. Biochim Biophys Acta. 2016;1860: 1623-39. PMID: 26968459

31. Napoletano C, Zizzari IG, Rughetti A, Rahimi H, Irimura T, Clausen $H_{\text {, et }}$ al. Targeting of macrophage galactose-type C-type lectin (MGL) induces DC signaling and activation. Eur J Immunol. 2012;42:936-45. PMID: 22531918

32. Lo-Man R, Vichier-Guerre S, Bay S, Dériaud E, Cantacuzène D, Leclerc C Anti-tumor immunity provided by a synthetic multiple antigenic 
glycopeptide displaying a Tri-Tn glycotope. J Immunol. 2001;166:284954. PMID: 11160353

33. SAF J, Quintero-Martinez, Ouyang $X$, et al. Organization of the extracellular portion of the macrophage galactose receptor: A trimeric cluster of simple binding sites for $\mathrm{N}$-acetylgalactosamine. Glycobiology. 2013;23:853-64 PMID: 23507965

34. Garg S, Oran A, Wajchman J, Sasaki S, Maris CH, Kapp JA, et al. Genetic tagging shows increased frequency and longevity of antigenpresenting, skin-derived dendritic cells in vivo. Nat Immunol. 2003;4: 907-12. PMID: 12910266

35. Tomura M, Hata A, Matsuoka S, Shand FH, Nakanishi Y, Ikebuchi R, et al. Tracking and quantification of dendritic cell migration and antigen trafficking between the skin and lymph nodes. Sci Rep. 2014;4:6030. PMID: 25112380

36. Kitano M, Yamazaki C, Takumi A, Ikeno T, Hemmi H, Takahashi N, et al. Imaging of the cross-presenting dendritic cell subsets in the skin-draining lymph node. Proc Natl Acad Sci USA. 2016;113:1044-9. PMID: 26755602

37. Grewal PK. The Ashwell-Morell receptor. Methods Enzymol. 2010;479:223-41. PMID: 20816169

38. Weigel PH, Yik JHN. Glycans as endocytosis signals: the cases of the asialoprotein and hyaluronan/chrondroitin sulfate receptors. Biochim Biophys Acta. 2002;1572:341-63. PMID: 12223279

39. Feinberg H, Torgersen D, Drickamer K, Weiss WI. Mechanism of pHdependent $\mathrm{N}$-acetylgalactosamine binding by a functional mimic of the hepatic asialoglycoprotein receptor. J Biol Chem. 2000;275:35176-84. PMID: 10931846

40. Schwartz AL, Rup D, Lodish HF. Difficulties in the quantification of asialoglycoprotein receptors on the rat hepatocyte. J Biol Chem. 1980;255: 9033-6. PMID: 7410410

41. Bon C, Hofer T, Bousquet-Mélou A, Davies MR, Krippendorff BF. Capacity limits of asialoglycoprotein receptor-mediated liver targeting. MAbs. 2017;9: 1360-9. PMID: 28876162

42. Yamamoto K, Ishida C, Shinohara Y, Hasegawa Y, Konami Y, Osawa T, Irimura T. Interaction of immobilized recombinant mouse C-type macrophage lectin with glycopeptides and oligosaccharides. Biochemistry. 1994:33:8159-66. PMID: 7517698

43. Khorev O, Stokmaier D, Schwardt O. Cutting B, Ernst B. Trivalent, Gal/ GalNAc-containing ligands designed for asialoglycoprotein receptor. Bioorg Med Chem. 2008;16:5216-31. PMID: 18358727

44. Dixon LJ, Barnes M, Tang H, Pritchard MT, Nagy LE. Kupffer Cells in the Liver. Compr Physiol. 2013;3:785-97. PMID: 23720329

45. Coombs PJ, Taylor ME, Drickamer K. Two categories of mammalian galactose-binding receptors distinguished by glycan array profiling. Glycobiology. 2006;16:1C-7C. PMID: 16670103

46. van Vliet SJ, Bay S, Vuist IM, Kalay H, Garcia-Vallejo JJ, Leclerc C, van Kooyk Y. MGL signaling augments TLR2-mediated responses for enhanced IL-10 and TNF-a secretion. J Leukoc Biol 2013;94:315-323. PMID: 23744646

47. Eggink LL, Hoober JKA. biologically active peptide mimetic of $\mathrm{N}$ acetylgalactosamine/galactose. BMC Res Notes. 2009;2:23. PMID: 19284521

48. Kushchayev SV, Sankar T, Eggink LL, Kushchayeva YS, Wiener PC, Hoober JK, et al. Monocyte galactose/ $\mathrm{N}$-acetylgalactosamine-specific C-type lectin receptor stimulant immunotherapy of an experimental glioma. Part II: combination with external radiation improves survival. Cancer Manag Res. 2012;20:325-34. PMID: 23049281

49. Reche PA, Glutting J-P, Reinherz EL. Prediction of MHC class 1 binding peptides using profile motifs. Human Immunol. 2002;63:701-9. PMID: 12175724

50. Escobar H, Crockett DK, Reyes-Vargas E, Baena A, Rockwood AL, Jensen PE, Delgado JC. Large scale mass spectrometric profiling of peptides eluted from HLA molecules reveals $\mathrm{N}$-terminal-extended peptide motifs. J Immunol. 2008;181:4874-82. PMID: 18802091

51. Roby KF, Taylor CC, Sweetwood JP, Cheng Y, Pace JL, Tawfik O, et al. Development of a syngeneic mouse model for events related to ovarian cancer. Carcinogenesis. 2000;21:585-91. PMID: 10753190

52. Sanchez JF, Lescar J, Chazalet V, Audfray A, Gagnon J, Alvarez R, et al. Biochemical and structural analysis of Helix pomatia agglutinin: a hexameric lectin with a novel fold. J Biol Chem. 2006;281:20171-80. PMID: 16704980

53. Mammen M, Choi S-K, Whitesides GM. Polyvalent interactions in biological systems: implications for design and use of multivalent ligands and inhibitors. Angew Chem Int Ed. 1998;37:2754-94. https:// doi.org/10.1002/(SICI)1521-3773(19981102).
54. Cairo CW, Gestwicki JE, Kanai M, Kiessling LL. Control of multivalent interactions by binding epitope density. J Am Chem Soc. 2002;124:1615-9. PMID: 11853434

55. Dam TK, Gerken TA, Brewer CF. Thermodynamics of multivalent carbohydrate-lectin cross-linking interactions: importance of entropy in the bind and jump mechanism. Biochemistry. 2009;48:3822-7. PMID: 19292456

56. Vasileiou Z, Barlos K, Gatos D. Convergent solid-phase and solution approaches in the synthesis of the cysteine-rich Mdm2 RING finger domain. J Pept Sci. 2009;15:824-31. PMID: 19824037

57. Goldfarb AR, Saidel $\amalg$, Mosovich E. The ultraviolet absorption spectra of proteins. J Biol Chem. 1951;193:397-404. PMID: 14907727

58. Biasini M, Bienert S, Waterhouse A, Arnold K, Studer G, Schmidt T, et al. SWISS-MODEL: modelling protein tertiary and quaternary structure using evolutionary information. Nucleic Acids Res. 2014;42(W1):W252-8. https:// doi.org/10.1093/nar/gku340. PMID: 24782522

59. Benkert P, Biasini M, Schwede T. Toward the estimation of the absolute quality of individual protein structure models. Bioinformatics. 2011;27:34350. PMID: 21134891

60. Blaszczyk M, Kurcinski M, Kouza M, Wieteska L, Debinski A, Kolinski A, Kmiecik S. Modeling of protein-peptide interactions using the CABS-dock web server for binding site search and flexible docking. Methods. 2016;93: 72-83. PMID: 26165956

61. de Vries SJ, Rey J, Schindler CEM, Zacharias M, Tuffery P. The pepATTRACT web server for blind, large-scale peptide-protein docking. Nucleic Acids Res. 2017;45:W361-4. PMID: 28460116

62. Yan C, Xu X, Zou X. Fully blind docking at the atomic level for protein-peptide complex structure prediction. Structure. 2016;24:1842-53. PMID: 27642160

63. London N, Movshovitz-Attias D, Shueler-Furman O. The structural basis of peptide-protein binding strategies. Structure. 2010;18:188-99. PMID: 20159464

64. Trellet M, Melquiond ASJ, Bonvin AMJJA. unified conformational selection and induced fit approach to protein-peptide docking. PLoS One. 2013;8: e58769. PMID: 23516555

65. Weis WI, Drickamer K, Hendrickson WA. Structure of a C-type mannosebinding protein complexed with an oligosaccharide. Nature. 1992;360:127-34. PMID: 1436090

66. Drickamer K. Engineering galactose-binding activity into a C-type mannosebinding protein. Nature. 1992;360:183-6. PMID: 1279438

67. Guo Y, Feinberg H, Conroy E, Mitchell DA, Alvarez R, Blixt O, et al. Structural basis for distinct ligand-binding and targeting properties of the receptors DC-SIGN and DC-SIGNR. Nat Struct Mol Biol. 2004;11:591-8. PMID: 15195147

68. Huysamen C, Willment JA, Dennehy KM, Brown GD. CLEC9A is a novel activation C-type lectin-like receptor expressed on $\mathrm{BDCA}^{+}$dendritic cells and a subset of monocytes. J Biol Chem. 2008;283:16693-701. PMID: 18408006

69. Geijtenbeek TBH, Gringhuis SI. Signalling through C-type lectin receptors: shaping immune responses. Nat Rev Immunol. 2009;9:465-79. PMID: 19521399

70. Garcia-Vallejo JJ, van Kooyk Y. Endogenous ligands for C-type lectin receptors: the true regulators of immune homeostasis. Immunol Rev. 2009; 230:22-37. PMID: 19594627

71. Pillai S, Netravali IA, Cariappa A, Siglecs MH. immune regulation. Annu Rev Immunol. 2012;30:357-92. PMID: 22224769

72. Macauley MS, Crocker PR, Paulson JC. Siglec-mediated regulation of immune cell function in disease. Nat Rev Immunol. 2014;14:653-66. PMID: 25234143

73. Peach RJ, Hollenbaugh D, Stamenkovic I, Aruffo A. Identification of hyaluronic acid binding sites in the extracellular domain of CD44. J Cell Biol. 1993;122:257-64. PMID: 8314845

74. Marcelo F, Garcia-Martin F, Matsushita T, Sardinha J, Coelho H, Oude-Vrielink A, et al. Delineating binding modes of Gal/GalNAc and structural elements of the molecular recognition of tumor-associated mucin glycopeptides by the human macrophage galactose-type lectin. Chem Eur J. 2014;20:16147-55. PMID: 25324212

75. Tanaka J, Gleinich AS, Zhang Q, Whitfield R, Kempe K, Haddleton DM, et al. Specific and differential binding of $\mathrm{N}$-acetylgalactosamine glycopolymers to the human macrophage galactose lectin and asialoglycoprotein receptor. Biomacromolecules. 2017;18:1624-33. PMID: 28418238

76. Festing MFW, Legg R, Eydmann T, Brammal A. Mouse strain differences in resident peritoneal cells: a flow cytometric analysis. Lab. Animals. 1990;24: 53-62. PMID: 2304327

77. Mombaerts P, lacomini J, Johnson RS, Herrup K, Tonegawa S, Papaioannou VE. RAG-1-deficient mice have no mature B and T lymphocytes. Cell. 1992; 68:869-77. PMID: 1547488 
78. Eskander RN, Tewari KS. Emerging treatment options for management of malignant ascites in patients with ovarian cancer. Internat. J Women's Health. 2012;4:395-404. PMID: 22927770

79. Ahmed N, Stenvers KL. Getting to know ovarian cancer ascites: opportunities for targeted therapy-based translational research. Front Oncol. 2013;3:article 256; doi: https://doi.org/10.3389/fonc.2013.00256. PMID: 24093089

80. Jordan MA, Wilson L. Microtubules as a target for anticancer drugs. Microtubules as a target for anticancer drugs. Nat Rev Cancer. 2004;4:25365. PMID: 15057285

81. Magidson V, He J, Ault JG, O'Connell CB, Yang N, Tikhonenko I, et al. Unattached kinetochores rather than intrakinetochore tension arrest mitosis in taxol-treated cells. J Cell Biol. 2016;212:307-19. PMID: 26833787

82. Duraiswamy J, Kaluza KM, Freeman GJ, Coukos G. Dual blockade of PD-1 and CTLA-4 combined with tumor vaccine effectively restores T-cell rejection function in tumors. Cancer Res. 2013;73:3591-603. PMID: 23633484

83. Duraiswamy J, Freeman GJ, Coukos G. Therapeutic PD- 1 pathway blockade augments with other modalities of immunotherapy T-cell function to prevent immune decline in ovarian cancer. Cancer Res. 2013;73:6900-12. PMID: 23975756

84. Hawiger D, Inaba K, Dorsett Y, Guo M, Mahnke K, Rivera M, et al. Dendritic cells induce peripheral $T$ cell unresponsiveness under steady state conditions in vivo. J Exp Med. 2001;194:769-79. PMID: 11560993

85. Eggink LL, Salas M, Hanson CV, Hoober JK. Peptide sugar mimetics prevent HIV Type 1 replication in peripheral blood mononuclear cells in the presence of HIV-positive antiserum. AIDS Res Human Retrovir. 2010;26:149-60. PMID: 20156098

86. Eggink LL, Hoober JK. Peptide mimetics of terminal sugars of complex glycans. Glycobiol Insights. 2010;2:63-74. https://doi.org/10.4137/GBI.S4243.

87. Eggink LL, Spyroulias GA, Jones NG, Hanson CV, Hoober JKA. peptide mimetic of 5-acetylneuraminic acid-galactose binds with high avidity to siglecs and NKG2D. PLoS One. 2015;10:e0130532. PMID: 26110603

88. Klimmeck D, Hansson J, Raffel S, Vakhrushev SY, Trumpp A, Krijgsveld J. Proteomic cornerstones of hematopoietic stem cell differentiation: distinct signatures of multipotent progenitors and myeloid committed cells. Mol Cell Proteomics. 2012;11:286-302. PMID: 22454540

89. Degli-Esposti SMJ. Close encounters of different kinds: dendritic cells and NK cells take centre stage. Nat Rev Immunol. 2005;5:112-24. PMID: 15688039

90. Reschner A, Hubert P, Delvenne P, Boniver J, Jacobs N. Innate lymphocyte and dendritic cell cross-talk: a key factor in the regulation of the immune response. Clin Exp Immunol. 2008;152:219-26. PMID: 18336590

91. Zhang W. Xu W, Xiong S. Macrophage differentiation and polarization via phosphatidylinositol 3-kinase/Akt-ERK signaling pathway conferred by serum amyloid P component. J Immunol. 2011;187:1764-77. PMID: 21753147

92. Quezada SA, Peggs KS, Curran MA, Allison JP. CTLA4 blockade and GMCSF combination immunotherapy alters the intratumor balance of effector and regulatory T cells. J Clin Invest. 2006;116:1935-45. PMID: 16778987

93. Simpson TR, Fubin L, Montalvo-Ortiz W, Sepulveda MA, Bergerhoff K, Arce F, et al. Fc-dependent depletion of tumor-infiltrating regulatory $T$ cells codefines the efficacy of anti-CTLA-4 therapy against melanoma. J Exp Med. 2013:210:1695-710. PMID: 23897981

94. Rapoport EM, Khaidukov SV, Gaponov AM, Pazynina GV, Tsygankova SV, Ryzhov IM, et al. Glycan recognition by human blood mononuclear cells with an emphasis on dendritic cells. Glycoconjugate J. 2018;35:doi.org/10. 1007/s10719-017-9811-6. PMID: 29388006

95. van Vliet SJ, Gringhuis SI, Geijtenbeek TBH, van Kooyk Y. Regulation of effector T cells by antigen-presenting cells via interaction of the Ctype lectin MGL with CD45. Nat Immunol. 2006;7:1200-8. PMID: 16998493

96. Coombs PJ, Harrison R, Pemberton S, Quintero-Martinez A, Parry S, Hasiam SM, et al. Identification of novel contributions to high-affinity glycoproteinreceptor interactions using engineered ligands. J Mol Biol. 2010;396:685-96. PMID: 20004209

97. Hermiston ML. Xu Z, Weiss A. CD45: a critical regulator of signaling thresholds in immune cells. Annu Rev Immunol. 2003;21:107-37. PMID: 12414720

98. Tong A, Nguyen J, Lynch KW. Differential expression of CD45 isoforms is controlled by the combined activity of basal and inducible splicing- regulatory elements in each of the variable exons. J Biol Chem. 2005;280: 38297-304. PMID: 16172127

99. Xu Z, Weiss A. Negative regulation of CD45 by differential homodimerization of the alternatively spliced isoforms. Nat Immunol. 2002; 3:764-71. PMID: 12134145

100. Kumar V, Cheng P, Condamine T, Mony S, Languino LR, McCaffrey JC, et al. CD45 phosphatase inhibits STAT3 transcription factor activity in myeloid cells and promotes tumor-associated macrophage differentiation. Immunity. 2016:44:303-15. PMID: 26885857

101. McNeill L, Cassady RL, Sarkardei S, Cooper JC, Morgan G, Alexander DR. CD45 isoforms in T cell signaling and development. Immunol Lett. 2004;92: 125-34. PMID: 15081536

102. Seki I, Suzuki M, Miyasakaa N, Kohsakaa H. Expression of CD45 isoforms correlates with differential proliferative responses of peripheral $\mathrm{CD}^{+}$and CD8 ${ }^{+}$T cells. Immunol Lett. 2010;129:39-46. PMID: 20093141

103. Armstrong DK, Bundy B, Wenzel L, Huang HQ, Baergen R, Lele $S$, et al. Intraperitoneal cisplatin and paclitaxel in ovarian cancer. N Engl J Med. 2006;354:34-43. PMID: 16394300

104. Ansaloni L, Coccolini F, Morosi L, Ballerini A, Ceresoli M, Grosso G, et al. Pharmacokinetics of concomitant cisplatin and paclitaxel administered by hyperthermic intraperitoneal chemotherapy to patients with peritoneal carcinomatosis from epithelial ovarian cancer. Brit. J Cancer. 2015;112:306-12. PMID: 25461804

105. Sparreboom A, van Tellingen O, Nooijen WJ, Beijnen JH. Tissue distribution, metabolism and excretion of paclitaxel in mice. Anti-Cancer Drugs. 1996;7: 78-86. PMID: 8742102

106. Intlekofer AM, Thompson CB. At the bench: preclinical rationale for CTLA-4 and PD-1 blockade as cancer immunotherapy. J Leukoc Biol. 2013;94:25-39. PMID: 23625198

107. Mittica G, Genta S, Aglietta M, Valabrega G. Immune checkpoint inhibitors: a new opportunity in the treatment of ovarian cancer? Int J Molec Sci. 2016; 17:1169. https://doi.org/10.3390/ijms17071169. PMID: 27447625

108. Hamanishi J, Mandai M, Konishi I. Immune checkpoint inhibition in ovarian cancer. Int Immunol. 2016;28:339-48. PMID: 27055470

\section{Ready to submit your research? Choose BMC and benefit from:}

- fast, convenient online submission

- thorough peer review by experienced researchers in your field

- rapid publication on acceptance

- support for research data, including large and complex data types

- gold Open Access which fosters wider collaboration and increased citations

- maximum visibility for your research: over $100 \mathrm{M}$ website views per year

At BMC, research is always in progress.

Learn more biomedcentral.com/submissions 